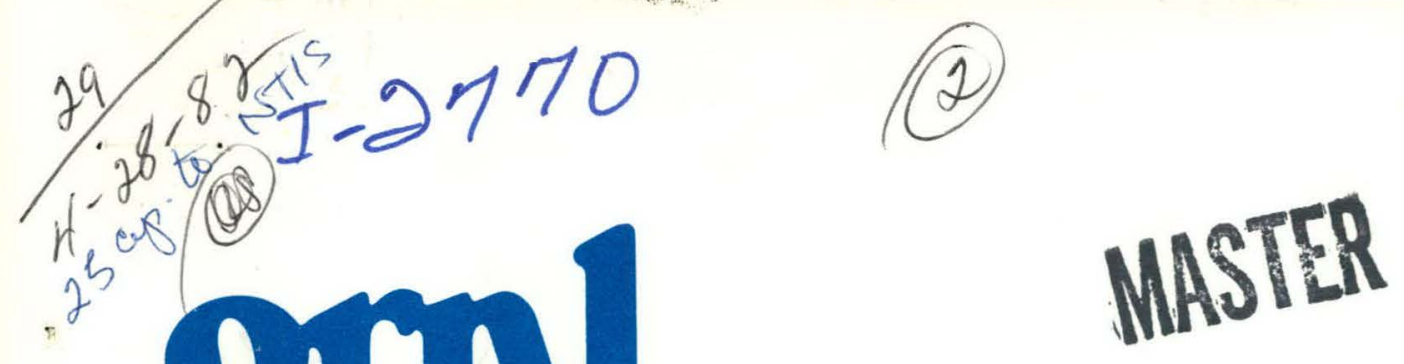

\title{
Separation of Alcohol-Water Mixtures Using Salts
}

\section{UNION \\ CARBIDE}

John C. Card

Luann M. Farrell

DO NOT MICROFILM COVER
OPERATED BY

UNION CARBIDE CORPORATION FOR THE UNITED STATES DEPARTMENT OF ENERGY 


\section{DISCLAIMER}

This report was prepared as an account of work sponsored by an agency of the United States Government. Neither the United States Government nor any agency Thereof, nor any of their employees, makes any warranty, express or implied, or assumes any legal liability or responsibility for the accuracy, completeness, or usefulness of any information, apparatus, product, or process disclosed, or represents that its use would not infringe privately owned rights. Reference herein to any specific commercial product, process, or service by trade name, trademark, manufacturer, or otherwise does not necessarily constitute or imply its endorsement, recommendation, or favoring by the United States Government or any agency thereof. The views and opinions of authors expressed herein do not necessarily state or reflect those of the United States Government or any agency thereof. 


\section{DISCLAIMER}

Portions of this document may be illegible in electronic image products. Images are produced from the best available original document. 
Printed in the United States of America. Available from National Technical Information Service

U.S. Department of Commerce

5285 Port Royal Road, Springfield, Virginia 22161

NTIS price codes-Printed Copy: A04; Microfiche A01

This report was prepared as an account of work sponsored by an agency of the United States Government. Neither the United States Government nor any agency thereof, nor any of their employees, makes any warranty, express or implied, or assumes any legal liability or responsibility for the accuracy, completeness, or usefulness of any information, apparatus, product, or process disclosed, or represents that its use would not infringe privately owned rights. Reference herein to any specific commercial product, process, or service by trade name, trademark, manufacturer, or otherwise, does not necessarily constitute or imply its endorsement, recommendation, or favoring by the United States Government or any agency thereof. The views and opinions of authors expressed herein do not necessarily state or reflect those of the United States Government or any agency thereof. 


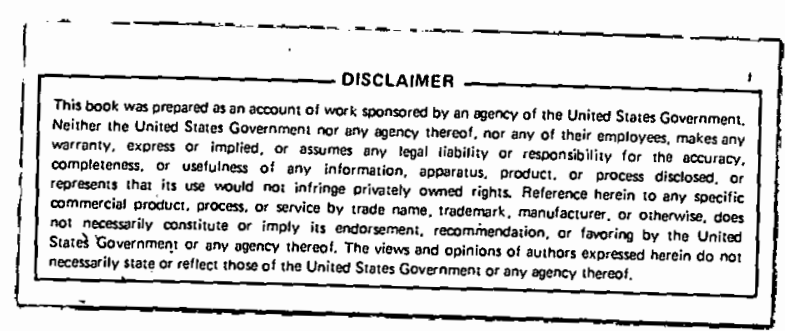

Contract No. W-7405-eng-26

SHEMICAL TES.HNOQI OGY DIVISION
ORNL/MIT -338

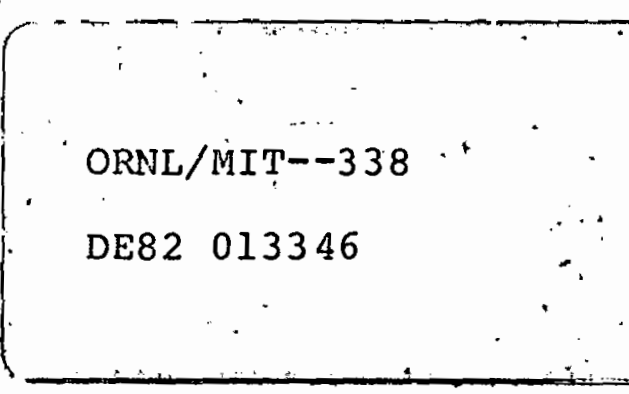

SEPARATION OF ALCOHOL-WATER MIXTURES USING SALTS

John C. Card

Luann M. Farrel 1

Consultants:

T.L. Donaldson, C.H. Brown, and G.W. Strandberg

Date Published - April 1982

ำ

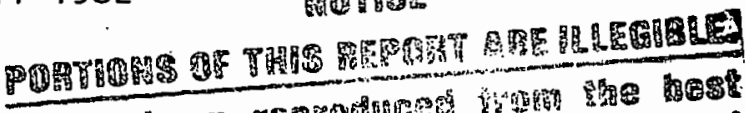

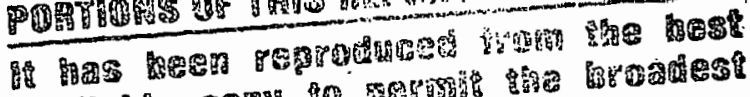
จง

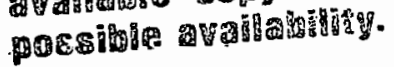

Oak Ridge Station

School of Chemical Engineering Practice

Massachusetts Institute of Technology

C.H. Byers, Director

;

Oak Ridge National Laboratory

Oak Ridge, Tennessee 37830

Operated by

Union Carbide Corporation

for the

Department of Energy 


\section{THIS PAGE \\ WAS INTENTIONALLY \\ LEFT BLANK}




\section{ABSTRACT}

Use of a salt ( $\mathrm{KF}$ or $\mathrm{Na}_{2} \mathrm{SO}_{4}$ ) to induce phase separation of alcoholwater mixtures was investigated in three process flowsheets to compare operating and capital costs with a conventional distillation process. The process feed was the Clostridia fermentation product, composed of 98 wt \% water and 2 wt \% solvents (70\% 1-butanol, 27\% 2-propanol, and 3\% ethanol). The design basis was $150 \times 10^{6} \mathrm{~kg} / \mathrm{y}$ of solvents. Phase equilibria and tieline data were obtained from literature and experiments.

Three separation-process designs were developed and compared by an incremental economic analysis $( \pm 30 \%)$ with the conventional separation technique using distillation alone. The cost of salt recovery for recycle was found to be the critical feature. High capital and operating costs make recovery of salt by precipitation uneconomical; however, a separation scheme using multiple-effect evaporation for salt recovery has comparable incremental capital costs $\left(\$ 1.72 \times 10^{6}\right.$ vs $\left.\$ 1.76 \times 10^{6}\right)$ and lower incremental operating costs $\left(\$ 2.14 \times 10^{6} / \mathrm{y}\right.$ vs $\left.\$ 4.83 \times 10^{6} / \mathrm{y}\right)$ than the conventional separation process. 


\section{THIS PAGE \\ WAS INTENTIONALLY \\ LEFT BLANK}




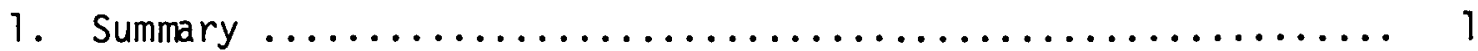

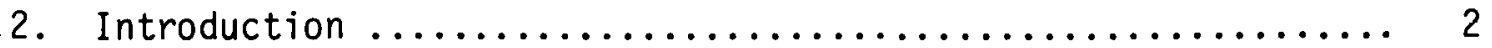

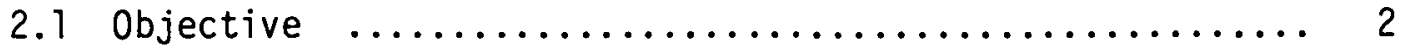

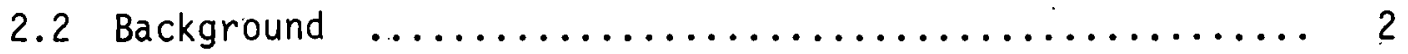

2.2.1 Conventional Separation Methods ............. 2

2.2.2 Proposed Separation Method .............. 8

2.3 Model Process Feedstream ..................... 8

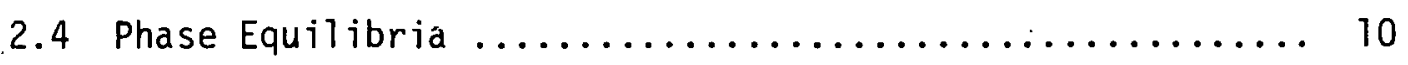

2.4.1 Choice of Solvent Composition ............. 10

2.4.2 Effect of Salt on the Butanol-Water-Salt Phase

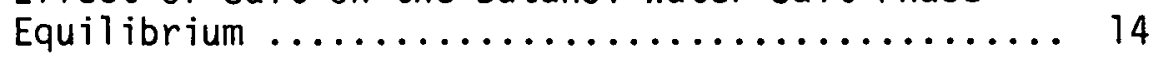

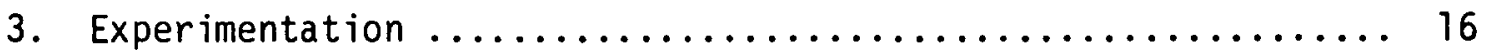

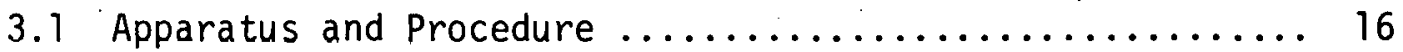

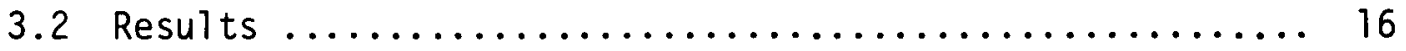

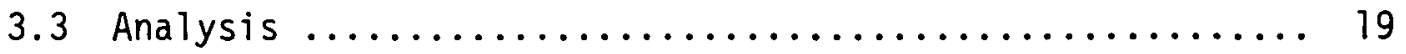

4. Separation-Process Design ...................... 19

4.1 Design Variables and Assumptions ............... 19

$4: 2$ Process-Design Results ...................... 22

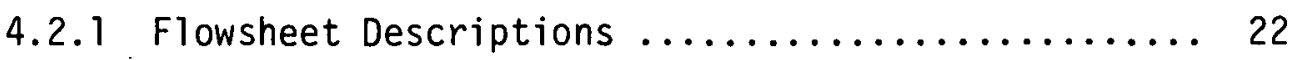

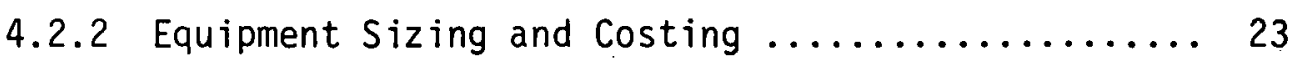

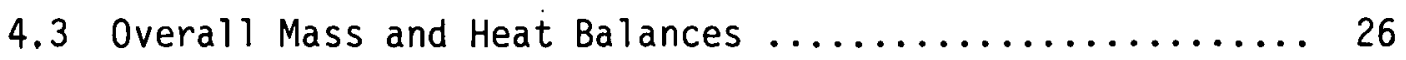

5. Comparison of Proposed Processes with Conventional Process ... 26

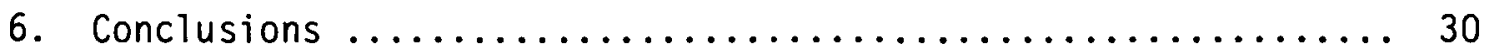

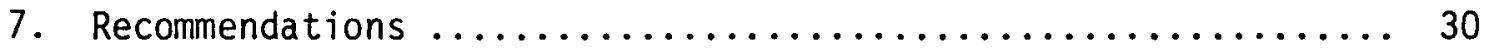

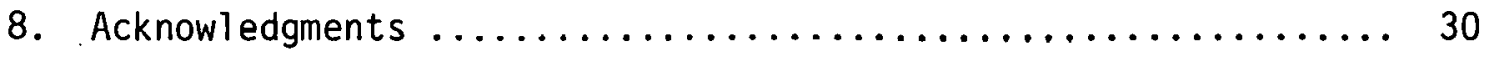

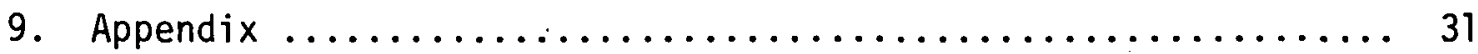

9.1 Physical Properties ........................ 31

9.2 Sample Calculations ..................... 33

9.3 Nomenclature.$\ldots \ldots \ldots \ldots \ldots \ldots \ldots \ldots \ldots \ldots \ldots \ldots$

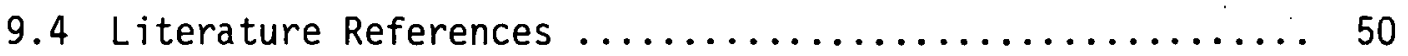




\section{SUMMARY}

Recently much research has focused on bioconversion as a means of producing alcohols and chemical feedstocks from renewable resources. Although several separation techniques, including extractive and azeotropic distillation, can separate alcohol-water mixtures, lower cost separation techniques are needed to improve bioconversion process economics. T.L. Donaldson, Chemical Technology Division, proposed using a salt to effect a phase separation in the alcohol-water mixtures. A concentrated alcoholrich phase could be formed in a single step and would result in smaller downstream distillation columns using less energy.

To evaluate this proposal, a well-known system containing several alcohols was chosen for investigation, namely the neutral-solvent product from Clostridia fermentation. The fermentation product studied was a mixture of 98 wt \% water and 2 wt \% solvents, composed of $70 \% 1$-butanol, $27 \%$ 2-propanol, and $3 \%$ ethanol. A 1 iterature survey of phase-equilibria data was conducted to determine the effect of a wide variety of salts on the phase equilibrium of this system. Based on this survey, $\mathrm{KF}$ and $\mathrm{Na}_{2} \mathrm{SO}_{4}$ were identified as effective salts for producing the desired phase separation. Since alcohol/water/salt phase-equilibrium data for these two salts were available for ethanol and 2-propanol, but not 1-butanol, these latter data were determined experimentally. Equilibrium-tieline data for the 1-butanol/water/salt system were estimated for design calculations, based on the available tieline data for the propanol and ethanol systems.

Utilizing these data, three alternative process designs were developed and compared economically with the conventional separation process for this system. An incremental economic analysis ( $\pm 30 \%$ accuracy) was performed in which only the features of the four processes that differed were compared; all other costs were assumed equal. All processes were based on a net-solvents production of $150 \times 10^{6} \mathrm{~kg} / \mathrm{y}$.

The cost of salt recovery was found to be the dominant feature in comparisons of the three proposed processes. One process using $\mathrm{Na}_{2} \mathrm{SO}_{4}$, based on precipitation for salt recovery, was found to have higher incremental capital costs $\left(\$ 4.26 \times 10^{6}\right.$ versus $\left.\$ 1.76 \times 10^{6}\right)$ and much higher incremental operating costs $\left(\$ 165.4 \times 106 / y\right.$ versus $\left.\$ 4.83 \times 10^{6} / \mathrm{y}\right)$ than the conventional separation. These high operating costs resulted from replacing the large quantities of salt which were unrecoverable by precipitation alone.

Multiple-effect evaporation was found to be a much more economical means of salt recovery. A process design using KF and multiple-effect evaporation for salt recovery had incremental capital costs comparable with the conventional separation $\left(\$ 1.72 \times 10^{6}\right.$ versus $\left.\$ 1.76 \times 10^{6}\right)$ and much more favorable incremental operating costs $\left(\$ 2.14 \times 10^{6} / y\right.$ versus $\$ 4.83 \times 106 / y)$. Based on these results, recommendations are made to optimize the proposed process for possible use in alcohol recovery from Clostridia fermentation, and al so to investigate the application of this separation technique to other organic/aqueous systems. 


\section{INTRODUCTION}

\subsection{Objective}

Our objective was to develop a separation process that uses salt to separate alcohol-water mixtures, and to compare this process economically with traditional separation schemes. This preliminary evaluation was to be a study estimate of probable error up to $\pm 30 \%$ (1). To achieve this objctive, it was necessary to:

1. Develop criteria for choosing an effective salt, based on a literature search of phase-equilibrium data for alcohol/water/salt systems.

2. Obtain laboratory phase-equilibrium data (phase envelope and tielines) to supplement the data not available in the literature.

3. Design a separation process based on the equilibrium data obtained.

4. Compare the economics of this process with that of a conventional separation in an incremental economic analysis based on a total-alcohols production of $150 \times 10^{6} \mathrm{~kg} / \mathrm{y}$, assuming $95 \%$ product purity and $95 \%$ solvents recovery.

\subsection{Background}

\subsubsection{Conventional Separation Methods}

Alcohol-water mixtures can be separated by several methods, such as distillation, extraction, or a combination of both. The lowest-cost technique for many chemicals is distillation, since many mixtures can be separated directly into pure products without further processing. However, many of the commonly encountered alcohol-water mixtures (ethanol-, propanol-, butanol-water) form azeotropes, which make separation into pure components impossible by simple distillation. In these systems, variations on simple distillation are employed to effect separation. Two such techniques are azeotropic and extractive distillation. These processes are described. in detail by McCabe and Smith (2), Treybal (3)), Benedict and Rubin (4), and Smith (5) and are summarized here.

In extractive distillation a solvent not present in the mixture is added to increase the difference in volatility between the key components to be separated. The solvent is less volatile than the key components; it is fed near the top of the distillation column and is removed from the column with the bottoms (see Fig. 1). A second distillation tower is necessary for solvent recovery and purification of the second product.

Alternatively, several variations of azeotropic distillation can be used to separate alcohol-water mixtures, depending on the vapor-liquid 


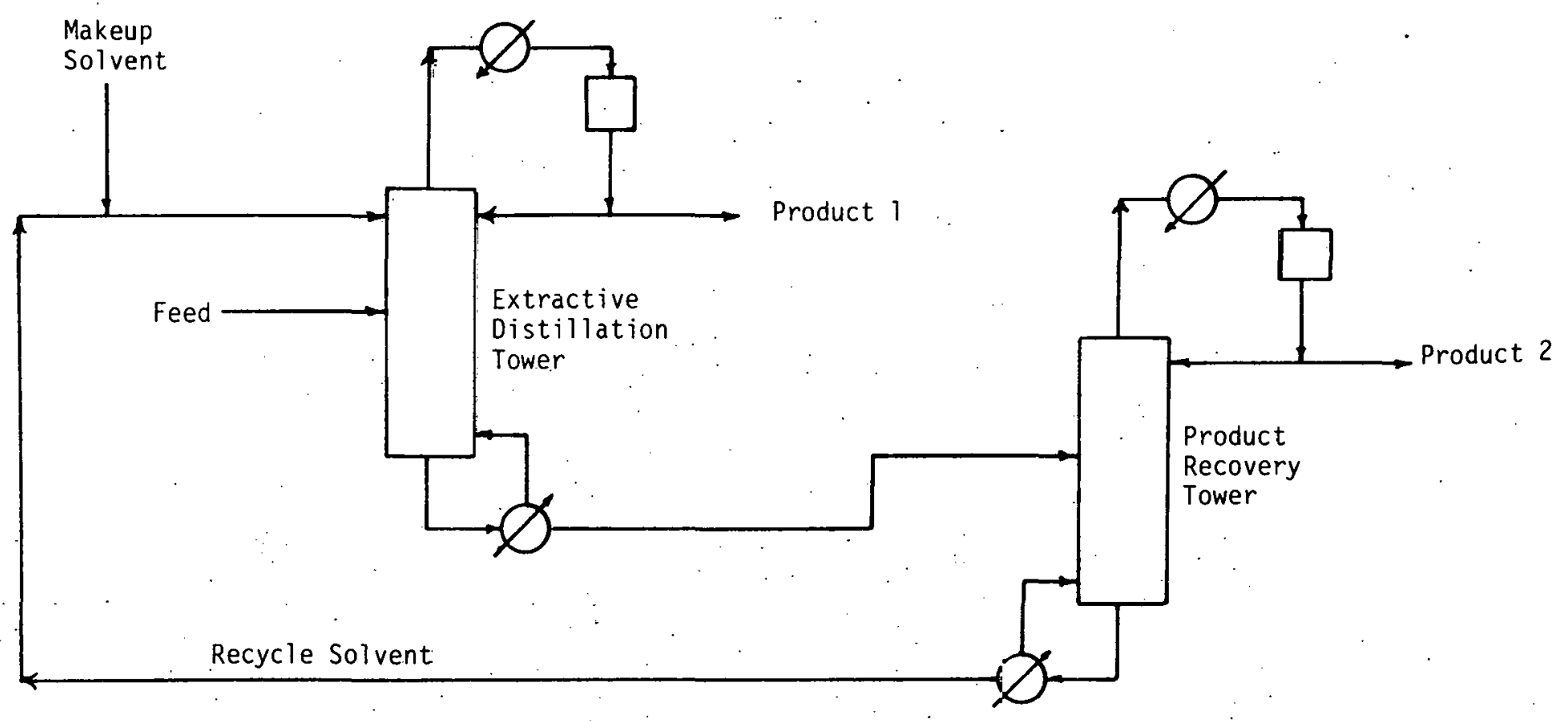

MASSACHUSETTS INSTITUTE OF TECHNOLOGY SCHOOL OF CHEMICAL ENGINEERING PRACTICE OAK RIDGE NATIONAL LABORATORY

SEPARATION OF MIXTURE

BY EXTRACTIVE DISTILLATION

\begin{tabular}{|c|c|c|}
\hline $\begin{array}{l}\text { DATE } \\
10-16-81\end{array}$ & $\begin{array}{c}\text { DRAWN BY } \\
\text { JCC }\end{array}$ & \begin{tabular}{|l|} 
FILE NOO \\
CEPS- $X-338$
\end{tabular} \\
\hline
\end{tabular}


equilibrium characteristics of the system involved. For example, the 1-butanol/water system exhibits a miscibility gap between liquid butanol mole fractions 0.02 and 0.45 (see Fig. 2a). At temperatures below approximately $92^{\circ} \mathrm{C}$, any 1 -butanol/water mixture with butanol mole fraction in this range will spontaneously separate into two phases, whose mole fractions are given by the endpoints. This property of the 1-butanol/water system can be exploited in an azeotropic distillation scheme. Since the miscibility gap crosses the azeotrope (note the intersection of the equilibrium curve with the $X-Y$ line in Fig. 2b), the alcohol and water can be separated by a simple, two-column distillation scheme, as shown in Fig. 3a. In this design, the butanol column operates to the right of the azeotropic composition of the vapor-liquid equilibrium (VLE) curve, shown in Fig. 3b, separating the . butanol-water azeotrope from pure butanol. The water column operates to the left of the azeotropic composition in the VLE diagram in Fig. $3 \mathrm{~b}$, separating the butanol-water azeotrope from pure water.

Figure $3 b$ is a graphical representation of the operation of these columns on the VLE diagram by a McCabe-Thiele analysis (3). The azeotrope is the overhead product of both columns since its boiling point is below that of either pure component. The azeotrope is condensed and fed to a decanter, where it spontaneously separates into two phases. The butanol-rich phase is refluxed to the top stage of the butanol column, while the water-rich phase is refluxed to the top stage of the water column. It must be stressed that this process is effective only because the 1-butanol/water system forms a heterogeneous azeotrope, i.e., one that spontaneously separates into two phases. If this were not the case, a decanter would not be sufficient to separate the overhead azeotrope product, and another, more expensive, separation process would be required.

Other simple alcohols, such as ethanol and propanol do not form heterogeneous azeotropes in water, and so more-complicated separation schemes are required. Ethanol, like 2-propanol and 1-butanol, forms a minimum-boiling azeotrope with water. To effect separation, a distillation scheme such as that of Fig. 4 can be used. Benzene is added to the ethanol-water mixture. This forms a minimum-boiling ternary azeotrope with ethanol and water, which boils at a lower temperature than the ethanol/ water binary azeotrope. The ternary azeotrope contains a higher ratio of water than the ethanol/water azeotrope. The. ternary azeotrope flows overhead from the primary column, removing all the water and benzene, leaving pure ethanol as the bottoms product. When the overhead is condensed and sent to a decanter, it spontaneously separates into a twophase mixture. The upper benzene-rich phase is returned as reflux to the primary column, while the lower water-rich phase is fed to a secondary column, which also produces the ternary azeotrope as the overhead product. The bottom product from the secondary column is a mixture of alcohol and water, which is split in a third tower into a bottom product of pure water and an overhead product which is the ethanol-water binary azeotrope. This overhead stream is recycled to the primary column. This process is made effective only by use of benzene, or a similar substance, to push the ethanol-water feed composition past the binary azeotropic composition. 


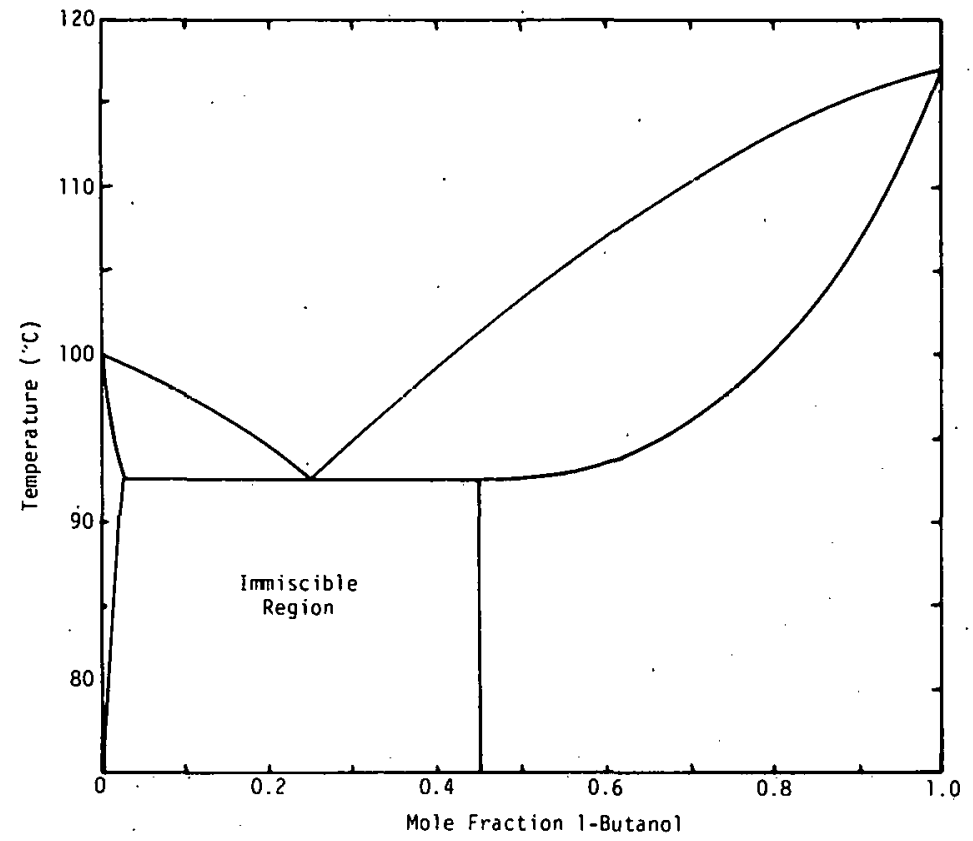

$2 a$

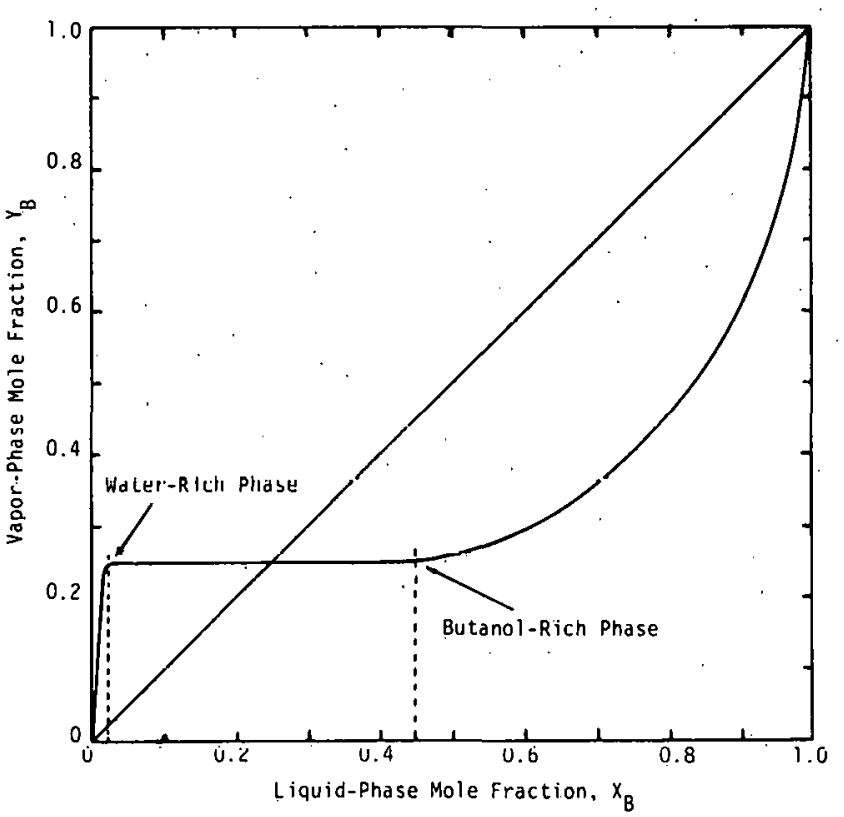

$2 b$.

MASSACMUSETTS INSTITUTE OF TECHNOLOG SCHOOL OF GHEMIGAL ENGINEERIMG PRASTICE OAK RIDGE NATIONAL LABORATORY

1-BUTANOL/WATER EQUILIBRIUM DATA ILLUSTRATING THE MISCIBILITY GAP

\begin{tabular}{|c|c|c|c|}
\hline OAT & DOAWM QY & FILE NO & FIS. \\
$10-17-81$ & JCC & EEPS-X-338 & 2 \\
\hline
\end{tabular} 


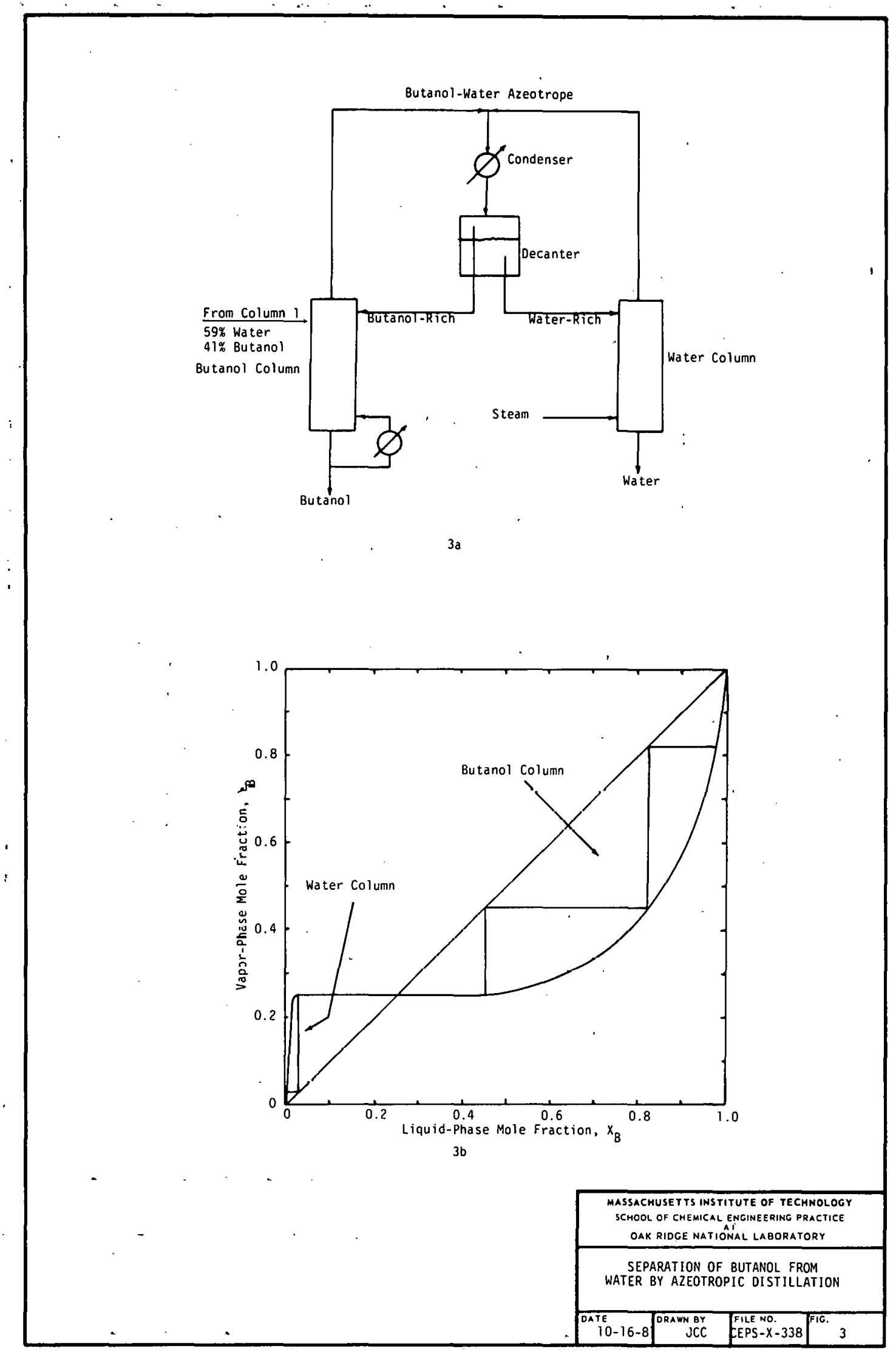




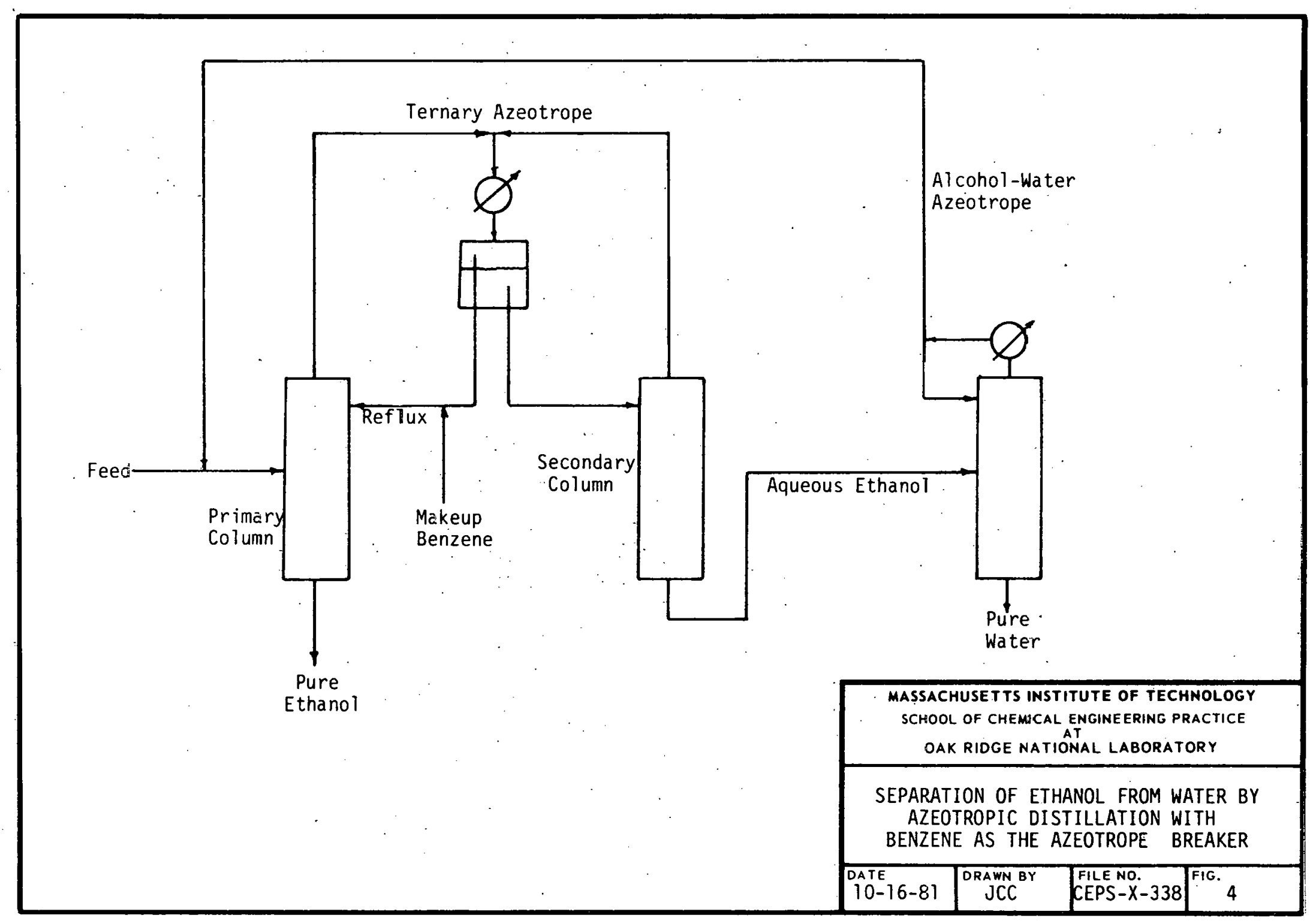




\subsubsection{Proposed Separation Method}

An alternative process, proposed by T.L. Donaldson ( $\underline{6})$, is to effect the separation of the alcohol/water mixture into two immiscible phases by the addition of a salt instead of a solvent. The salt decreases the solubility of the alcohol in water, resulting in the formation of a water-rich phase and an alcohol-rich phase. As with solvent processing in extractive or azeotropic distillation, salt processing is required in this technique. However, only the alcohol-rich phase would need to pass through distillation columns for separation; the water-rich phase would be removed in a decanter previous to the columns, as shown in Fig. 5. This could result in smaller downstream distillation columns and possibly lower energy costs. This assumes that the salt will have a very low solubility in the organic phase.

For butanol/water mixtures, where a miscibility gap already exists, the addition of salt would cause the gap to expand, and thus form a richer alcohol-rich phase and a leaner alcohol-lean phase. This would reduce the number of equilibrium stages needed in both columns of Fig. 3 .

For ethanol/water and propanol/water mixtures, where no miscibility gap exists, the addition of salt would also cause the formation of an alcohol-rich phase and an alcohol-lean phase. If a salt could be found that would push the composition of the alcohol-rich phase past the azeotropic composition, then pure alcohol and pure water could be obtained by using only two distillation columns. In any case, the absolute flow rates in the distillation columns would be reduced, which could result in capital and energy savings and in less energy consumption. To evaluate the potential of this separation technique, a model process feedstream was investigated.

\subsection{Model Process Feedstream}

The feedstream investigated was a mixture of 98 wt $\%$ water and 2 wt \% solvents, composed of 70 wt \% 1-butanol, 27 wt \% 2-propanol, and 3 wt \% ethanol. This mixture is typical of the fermentation products of the bacteria Clostridia. Several strains of Clostridia can be used to ferment many diverse forms of biomass including wood wastes, corn, and molasses to produce neutral solvents, such as 1-butanol, 2-propanol, acetone, and ethanol (7). From World War I through the late 1950s Clostridia fermentations were used commercially to produce l-butanol and acetone (8). The loss of inexpensive Cuban molasses feedstocks shifted U.S. production of neutral solvents to petroleum-based processes. However, rising petroleum costs and decreasing bioconversion costs may again make clostridia fermentation economically attractive $(\underline{9})$.

The fermentation products of the Clostridia system were chosen for investigation, not only because the clostridia system is well-known and is of general interest, but also because a wide variety of alcohols are produced. Several investigators are focusing on a strain of clostridium 


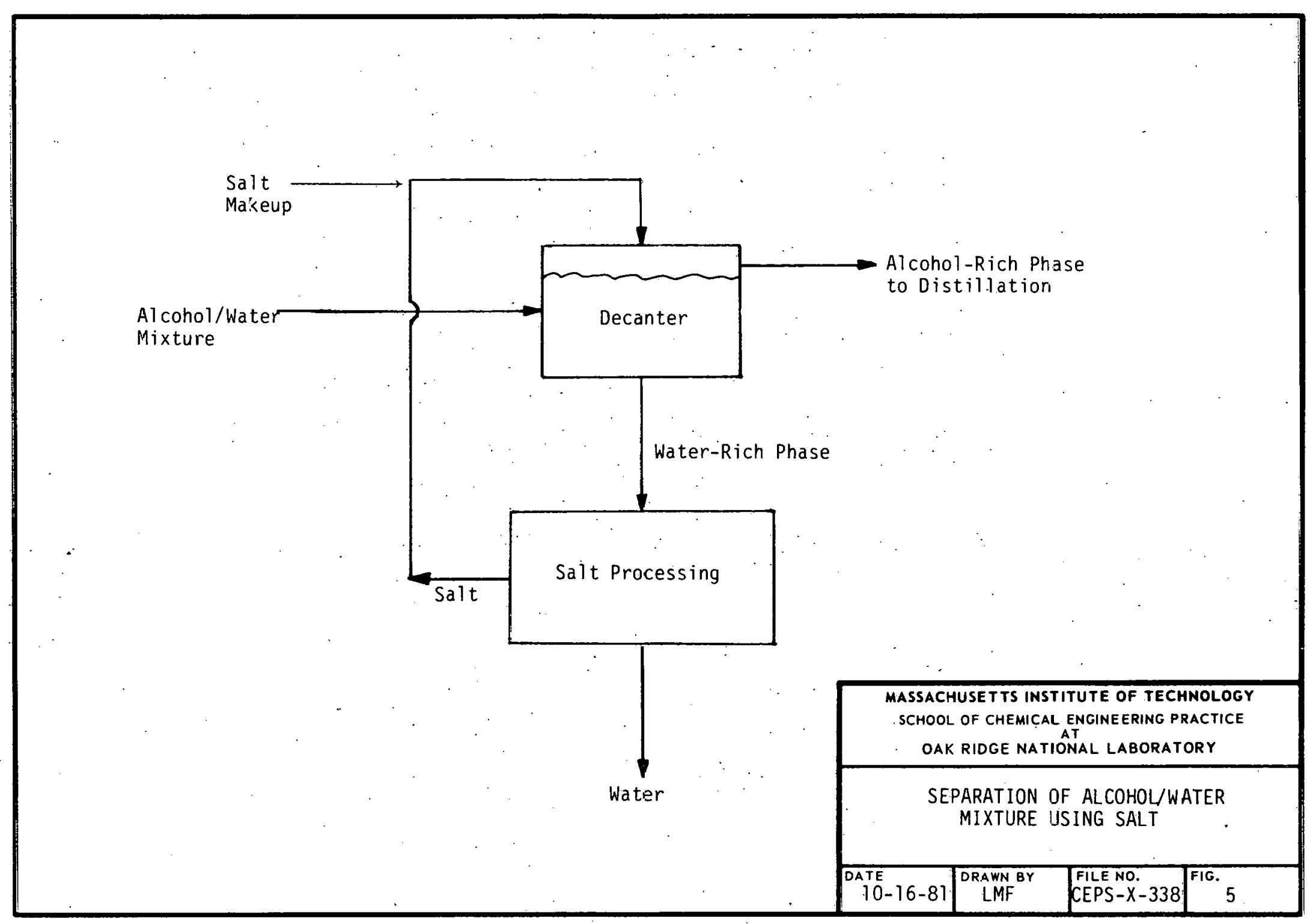


(Clostridia saccharoacetobutylicum) that produces 1-butanol, acetone, and ethanol. Another strain of Clostridium (Clostridia acmylo-saccharobutylpropylicum) ferments to 1-butanol, 2-propanol, and ethanol. It is a simulated fermentation broth of the latter strain that was investigated in this study. Thus, the effectiveness of salt in separating l-butanol, 2-propanol, and ethanol/water systems was investigated. These results were then compared with similar systems in different applications.

\subsection{Phase Equilibria}

\subsubsection{Choice of Solvent Composition}

The vapor-1 iquid equilibria for the 1-butanol/water system is presented in Fig. 2b. As previously discussed, a miscibility gap in the aqueous mixture exists between butanol mole fractions of 0.02 and 0.45 . This results in the formation of a water-rich phase and a butanol-rich phase, as labeled on Fig. 2b. If a third component, such as $\mathrm{NaCl}$, is added to the butanol/water mixture, the phase equilibrium of the system can be represented in a ternary diagrarm, as shown in Fig. 6 . These data were obtained from Stephen and Stephen (10). The corners of the triangle represent pure components, the edges are binary mixtures (weight percents), while any point within the triangle is a three-component mixture. The miscibility gap can also be observed on this diagram. It extends from point $A$ to point $B$, where $A$ is the water-rich phase, and $B$ is the butanol-rich phase.

If yet a fourth component such as acetone is added to this system, the phase equilibrium of the system can be represented by extending Fig. 6 into the third dimension, as shown in Fig. 7a. The quaternary diagram of Fig. 7a illustrates the phase equilibria only on the faces of the pyramid; no attempt was made to depict the three-dimensional surface within the pyramid. However, in this study the concentrations of salts and solvents are such that the points of interest within the pyramid are located very close to the faces. Therefore, to a good approximation, the phase equilibrium curves for these quaternary compositions can be approximated by the ternary phase equilibrium curves on the faces of the pyramid. This corresponds to assuming that the minor component alcohol behaves in the same manner as the major component alcohol. Phase equilibrium data for 1-butanol/water/ $\mathrm{NaCl} /$ acetone systems, containing 8 and $13 \mathrm{wt} \%$ acetone can be estimated by slicing the pyramid along these acetone compositions as shown in Fig. 7a. These slices are shown in Figs. $8 b$ and $8 c$. A similar analys is can be conducted for the 1-butanol/water/ $\mathrm{NaCl} / 2$-propanol system, the results of which are presented in $\mathrm{Figs} .7 \mathrm{~b}$ and $8 \mathrm{~d}$ through $8 \mathrm{f}$.

In Figs. 8a through $8 c$, notice that for even very small amounts of -acetone in the 1-butanol/water/ $\mathrm{NaCl} /$ acetone system, the miscibility gap shrinks considerably. This means that to distill butanol from this system with the separation scheme of Fig. 3a, many more distillation 


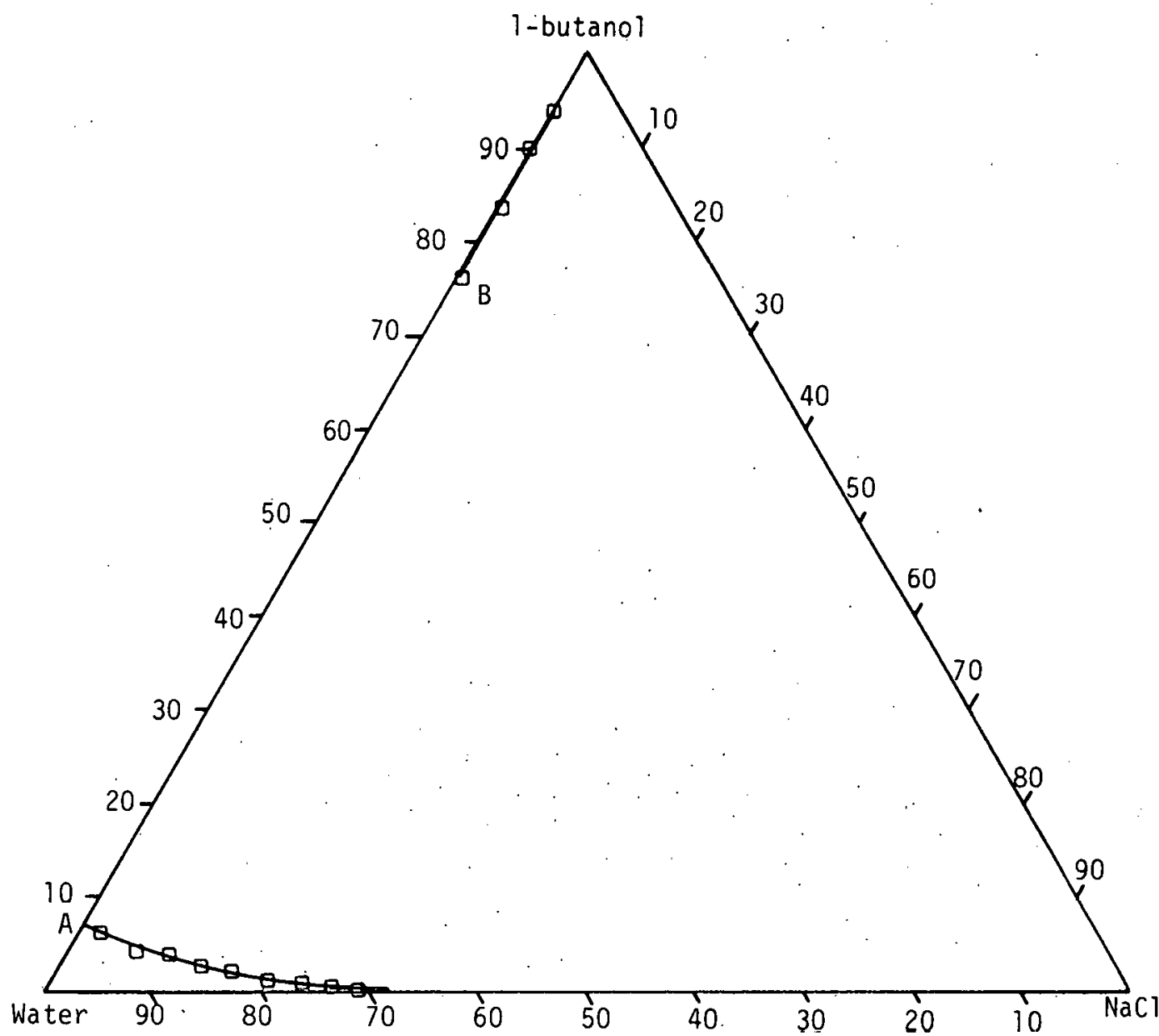

$$
\begin{aligned}
& P=1 \mathrm{~atm} \\
& T=20^{\circ} \mathrm{C}
\end{aligned}
$$

MASSACHUSETTS INSTITUTE OF TECHNOLOGY

SCHOOL OF CHEMICAL ENGINEERING PRACTICE

OAK RIDGE NATIONAL LABORATORY

PHASE-EQUILIBRIA DATA FOR

T-BUTANOL /WATER/NaCT SYSTEM (10)

\begin{tabular}{|l|l|l|l}
\hline DATE & DRAWN BY & FILE NO. & FIG. \\
\hline
\end{tabular}

\begin{tabular}{l|l|l|l|}
$10-17-81$ & JCC & CEPS $-X-339$ & 6
\end{tabular}


12
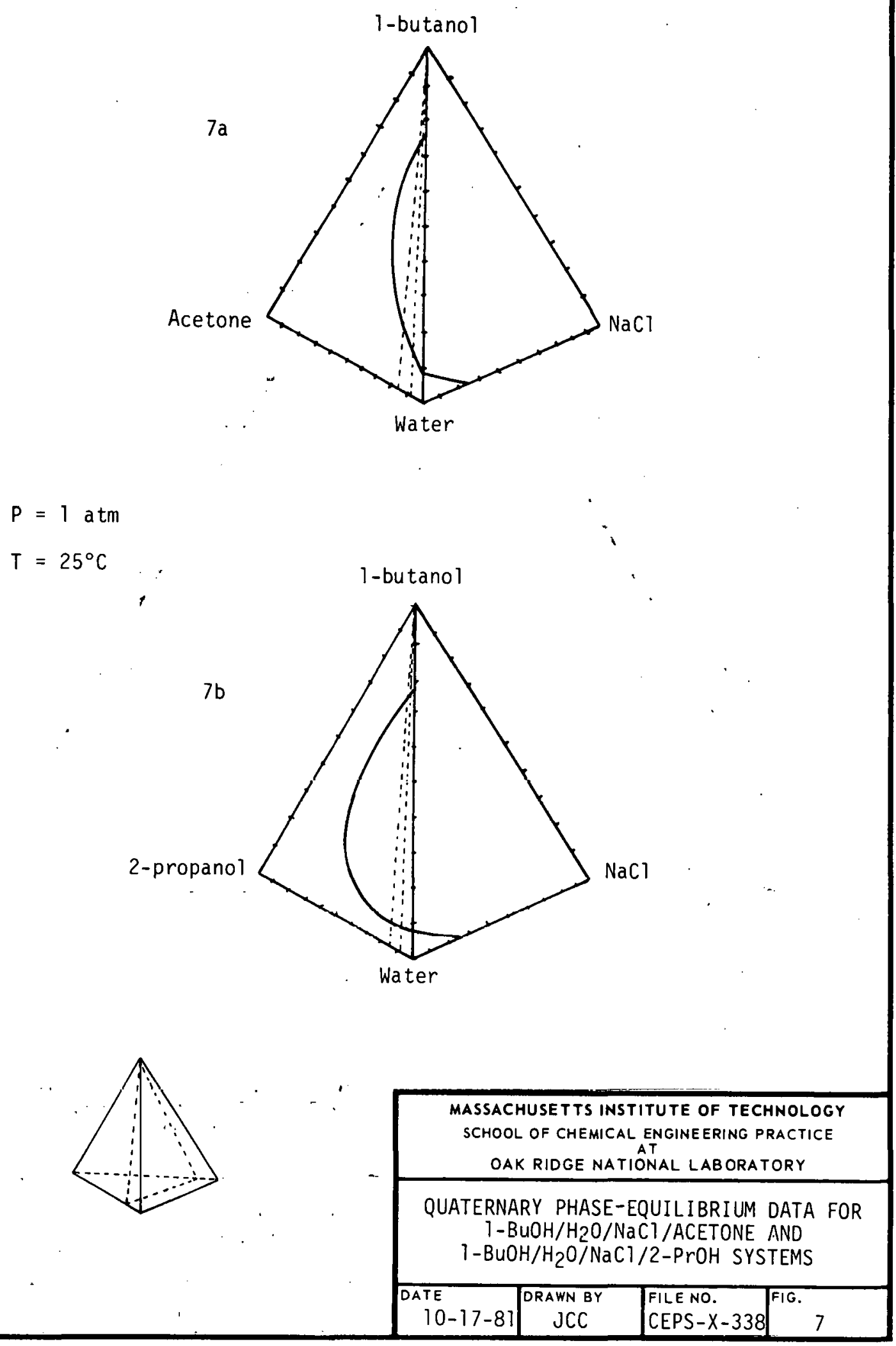


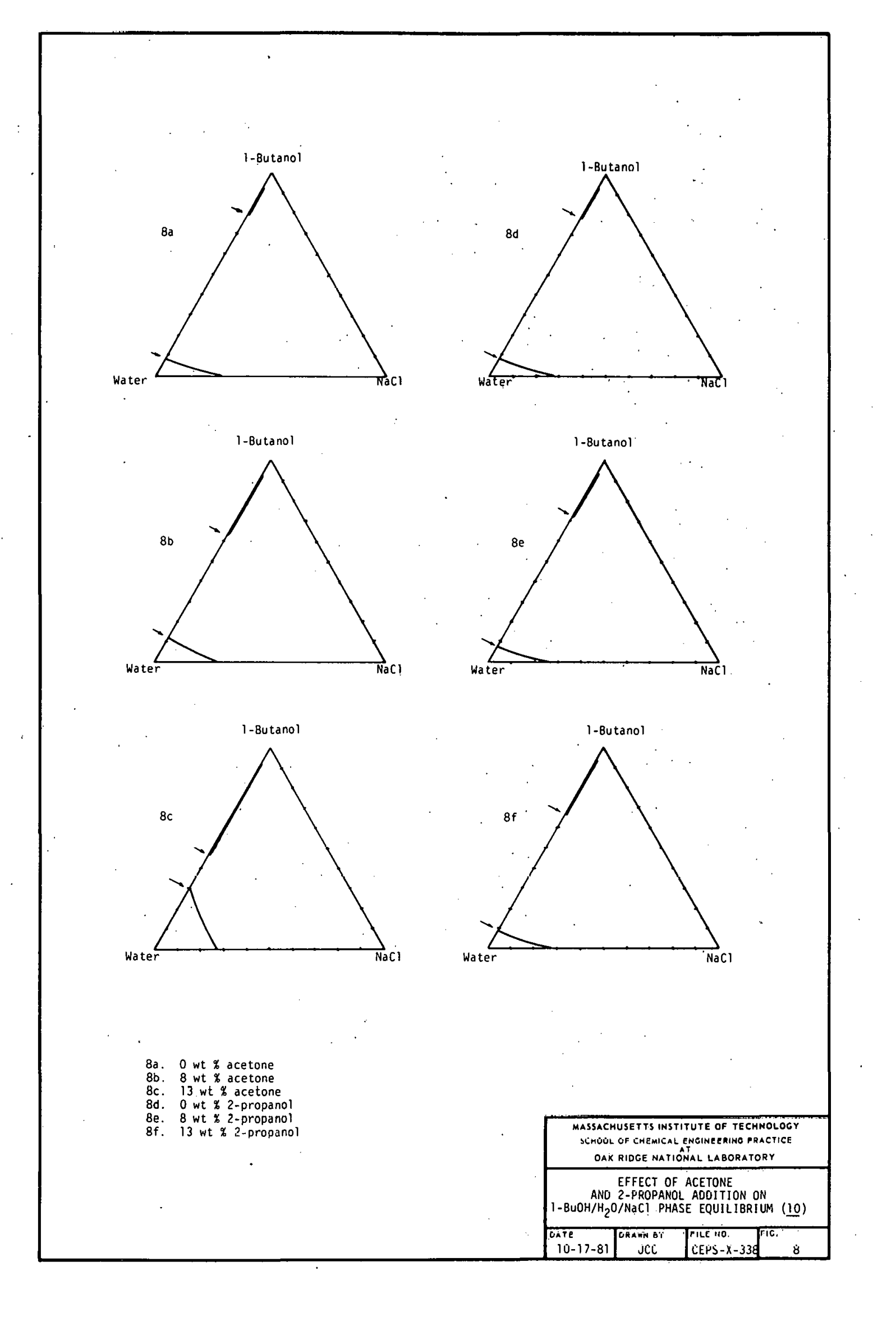


stages would be required. If more than 14 wt \% acetone is present in the system, the miscibility gap disappears altogether, and a more-complicated separation scheme than that of Fig. $3 a$ is required. In contrast, the presence of a moderate amount of 2-propanol (up to $15 \mathrm{wt} \%$ ) in the 1-butanol/ water/ $\mathrm{NaCl} / 2$-propanol system changes the butanol/water miscibility gap very little (Figs. 8d and $8 \mathrm{e}$ ). Thus, the butanol can be distilled from this system by the simple distillation scheme in Fig. 3a. It is for this reason that the 1-butanol/2-propanol/ethanol fermentation product was chosen over the 1-butanol/acetone/ethanol system for this study. A further simplifying assumption was made to neglect the ethanol, since it was present in very low concentration ( $<3$ wt $\%$ of total alcohols). A more detailed discussion of the behavior of this resulting ternary system is presented in the following section.

\subsubsection{Effect of Salt on the Butanol/Water/Salt Phase Equilibrium}

An extensive 1 iterature search was conducted, in which phase equilibrium data for more than 40 alcohol/water/salt systems were examined. Most of the data available pertains to ethanol systems; very 1 ittle 2-propanol and almost no 1-butanol data could be found. However, from the butanol and propanol data that are available, it was found that salts that effected good phase separation in ethanol/water systems were even more effective in propanol/water and butanol/water systems:

The criteria used to determine salt effectiveness are shown in Fig. 9. Phase-equilibrium data are presented for the ethanol/water/ $\mathrm{NaCl}$ and ethanol/water/NaF systems as given by Stephen and Stephen (10). The important features of an effective salt are shown by the NaF curve, while the $\mathrm{NaCl}$ curve shows a less effective salt. The upper part of the equilibrium curve should approach the pure alcohol apex of the ternary diagram as closely as possible. This results in an alcohol-rich phase of very high purity, requiring less energy consumption and fewer distillation stages to separate pure alcohol. Also, if the salt pushes this equilibrium curve to a Jiquid alcohol composition richer than the composition of the alcohol/water binary azeotrope, then a single distillation column, after phase separation, can yield pure alcohol. This alcohol-rich portion of the phase envelope should be close, if not tangent, to the alcohol/water leg of the triangle. This corresponds to a very low salt concentration in the alcohol-rich phase and minimizes downstream salt-removal problems.

The lower half of the phase envelope should approach the water-rich corner of the diagram, indicating little salt addition is necessary to affect phase separation. Thus, salts with low water solubility like NaF are preferred. For example, to push a 2 wt \% butanol feed within the phase envelope to achieve phase separation, 25 to $30 \mathrm{wt} \% \mathrm{NaCl}$ must be added to the mixture, while less than $5 \mathrm{wt} \%$ is required for NaF (Fig. 9). This allows smaller salt-recovery equipment to be used, which in turn lowers capital and operating costs.

Based on these observations, several trends in effectiveness were compiled. For a given cation, the anions ranked in order of decreasing 


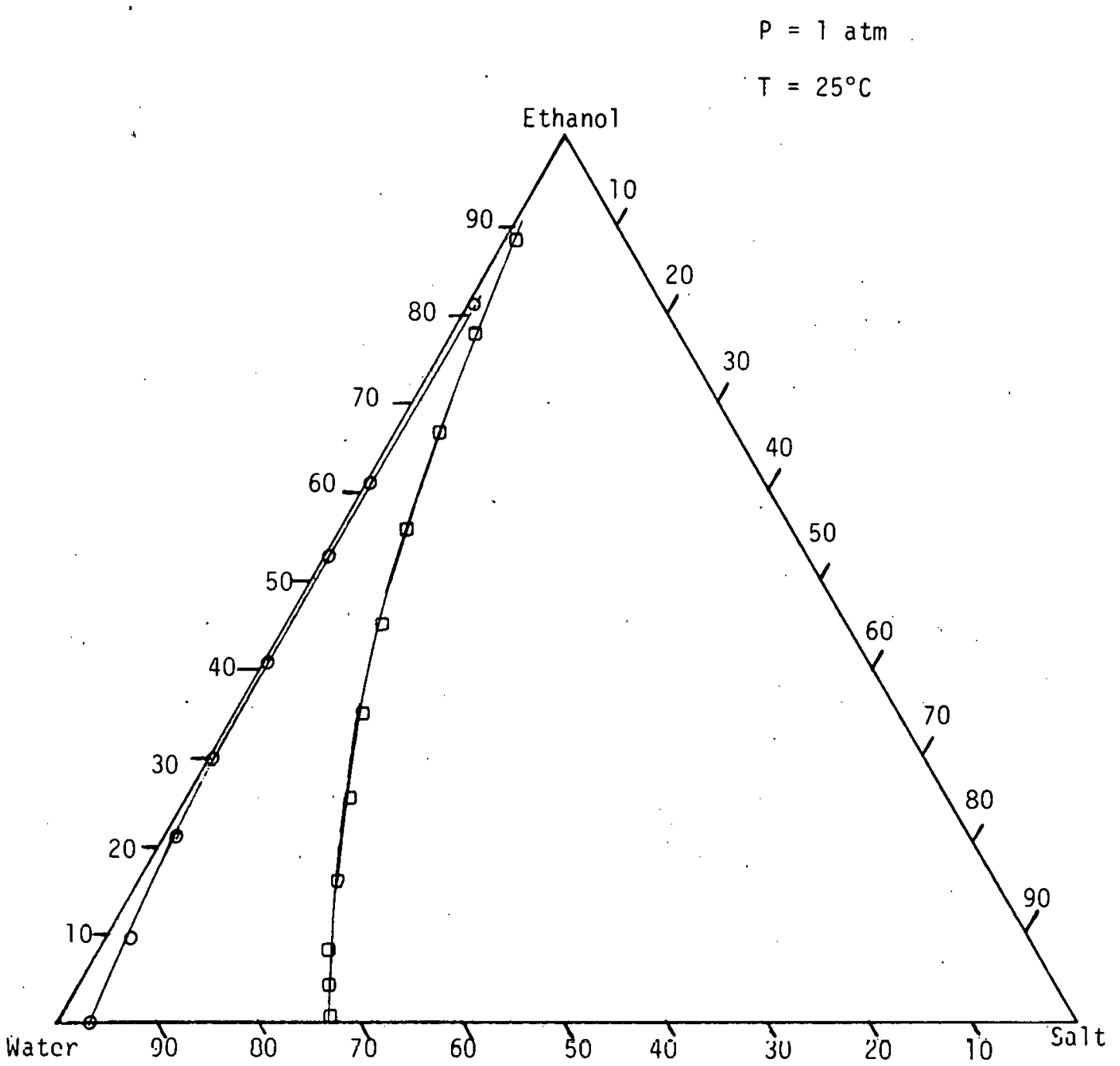

- $\mathrm{NaCl}$ (a bad salt)

MASSACHUSET TS INSTITUTE OF TECHNOLOGY

SCHOOL OF CHEMICAL ENGINEERING PRACTICE OAK RIDGE NATIONAL LABORATORY

- NaF (a good salt)

ILLUSTRATION OF A

GOOD AND A BAD SALT (10)

\begin{tabular}{|l|l|l|l}
\hline DATE & DRAWN BY & FILE NO. & FIG. \\
$10-16-81$ & LMF & CEPS-X-338 & 9
\end{tabular}


effectiveness are $\mathrm{F}^{-} \sim \mathrm{SO}_{4}^{-}>\mathrm{Cl}^{-} \sim \mathrm{CO}_{3}^{-}>\mathrm{Br}^{-}$. For a given anion, the cations ranked in order of decreasing effectivenes are $\mathrm{K}^{+} \sim \mathrm{Na}^{+}>\mathrm{Li}^{+}$. Thus, the most effective salts found were $\mathrm{KF}, \mathrm{NaF}$, and $\mathrm{Na}_{2} \mathrm{SO}_{4} . \mathrm{KF}$ and $\mathrm{Na}_{2} \mathrm{SO}_{4}$ were investigated in this study.

\section{EXPERIMENTATION}

\subsection{Apparatus and Procedure}

The experimental apparatus consisted of two burets used for titration ( 100 and $10 \mathrm{ml})$, a magnetically stirred beaker, and a gas chromatograph. Stock solutions of aqueous salt mixtures were prepared. Solutions of $1,2,5,10,20,30,40$, and $45 \mathrm{wt} \%$ potassium fluoride (KF) and 0.4 , $2.2,6.6$, and 7.1 wt \% sodium sulfate $\left(\mathrm{Na}_{2} \mathrm{SO}_{4}\right)$ were prepared.

To determine the phase envelope for a system, approximately 100 to $150 \mathrm{ml}$ of a stock solution was placed in a beaker and weighed. Pure 1-butanol was titrated from the 100-ml buret into the salt solution, while the solution was constantly stirred at room temperature (21 to $23.5^{\circ} \mathrm{C}$ ). l-Butanol addition was continued slowly until the solution became cloudy temporarily. The 10-mi buret was then used to add smaller aliquots of 1-butanol. When the solution remained cloudy after 1-butanol addition and 2 to $3 \mathrm{~min}$ of stirring, titration was discontinued. To determine the point at which the solution was cloudy, printed material was placed behind the beaker. When the fine print blurred, the solution was judged to be cloudy. The volume and weight of 1-butanol added were noted and recorded. A point on the 1-butanol/water/salt ternary diagram was thus determined. This process was repeated for all stock solutions of the two salts used to get one side of the miscibility curve.

To obtain tieline data, a known amount of 1-butanol was added to each of the mixtures on the phase envelope. The solutions were stirred vigorously, and alqquots were taken. In the sample bottles, the solution split into two phases: a lighter 1-butanol-rich phase and a heavier water-rich phase. Samples of each phase were diluted to approximately 0.1 wt \% 1-butanol and were then analyzed in a gas chromatograph (Perkin-Elmer, Model Sigma-2, with a Chromosorb 101 packed column operated at $150^{\circ} \mathrm{C}$ using a helium carrier gas).

\subsection{Results}

The phase diagram determined for the 1/butanol/water/KF system is shown in Fig. 10, and the diagram for 1-butanol/water $/ \mathrm{Na}_{2} \mathrm{SO}_{4}$ is shown in Fig. 11. The solid lines represent experimental data, while the dashed 1 ines represent estimates based on literature data $(\underline{9})$. 


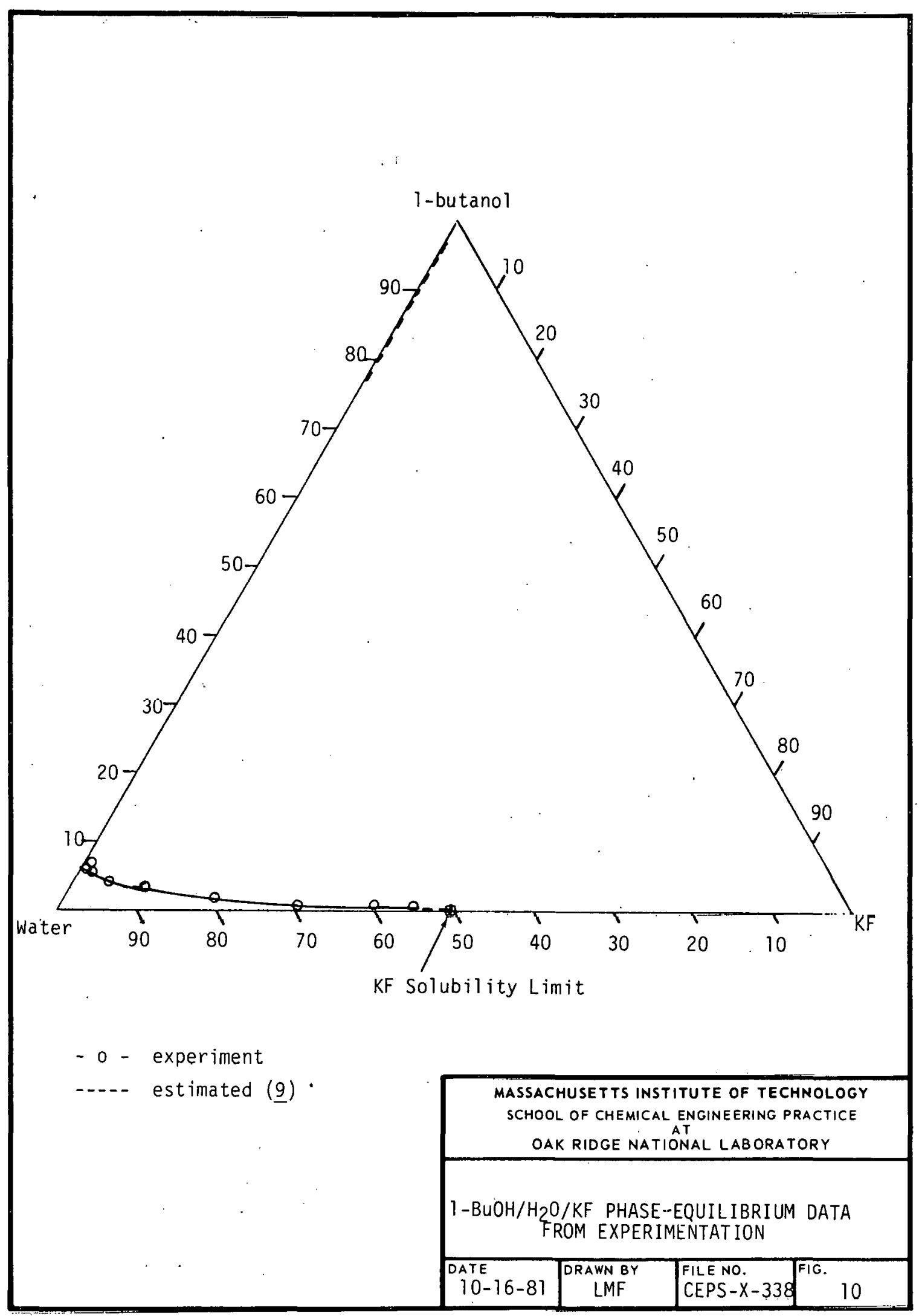




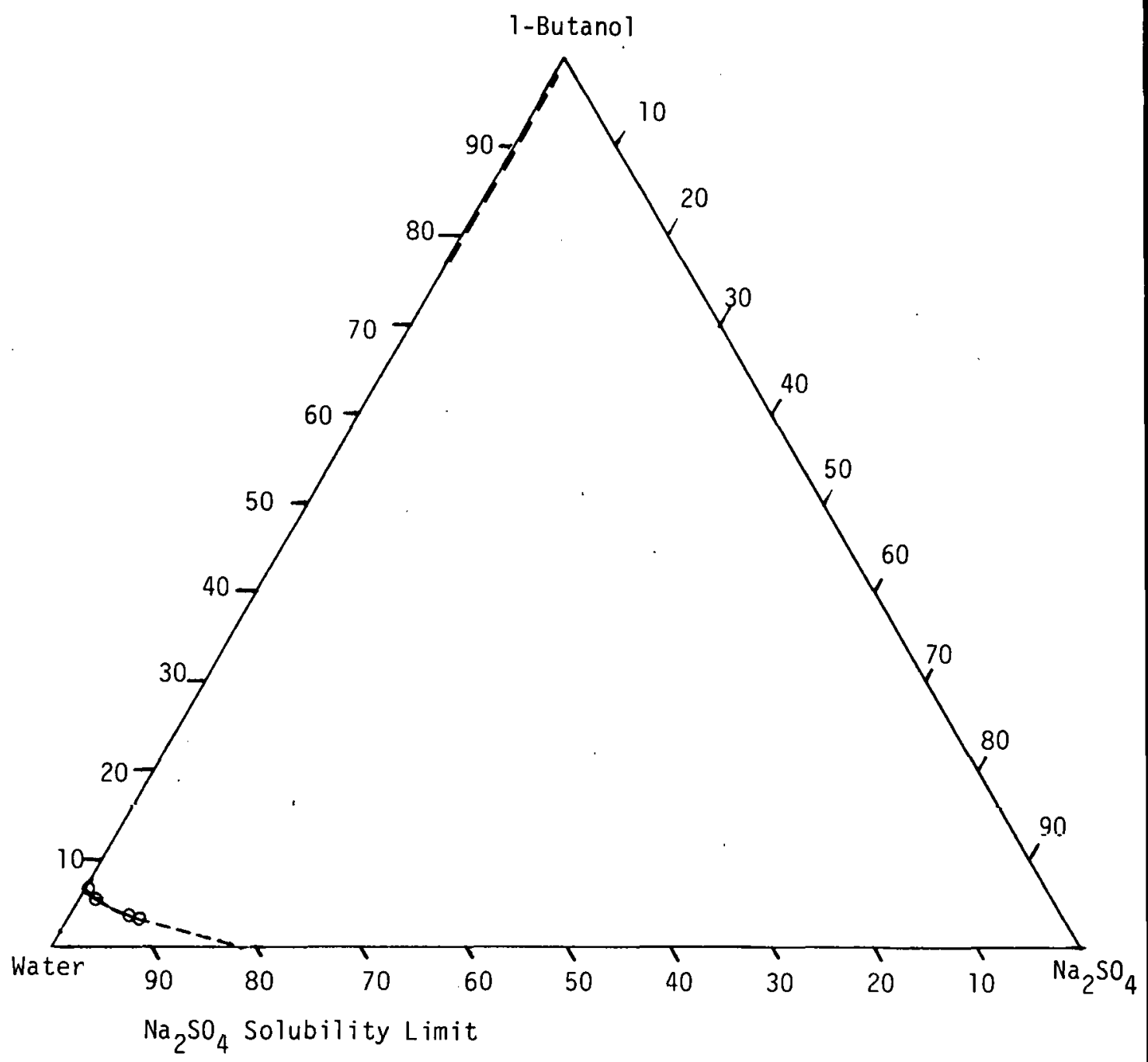

- o - experiment

-.--. estimated (9)

\begin{tabular}{|c|c|c|c|}
\hline \multicolumn{4}{|c|}{$\begin{array}{l}\text { MASSACHUSETTS INSTITUTE OF TECHNOLOGY } \\
\text { SCHOOL OF CHEMICAL ENGINEERING PRACTICE } \\
\text { OAK RIDGE NATIONAL LABORATORY }\end{array}$} \\
\hline \multicolumn{4}{|c|}{$\begin{array}{l}1 \text {-BUTANOL/WATER/ } \mathrm{Na}_{2} \mathrm{SO}_{4} \text { PHASE.- } \\
\text { EQUILIBRIUM DATA FROM EXPERIMENTATION }\end{array}$} \\
\hline $\begin{array}{l}\text { DATE } \\
10-16-81\end{array}$ & $\begin{array}{l}\text { DRAWN BY } \\
\text { LMF }\end{array}$ & $\begin{array}{l}\text { FILE NO. } \\
\text { CEPS-X-338 }\end{array}$ & FIG. \\
\hline
\end{tabular}




\subsection{Analys is}

Due to mechanical difficulties with the gas chromatograph, it was not possible to assay the equilibrium phases to obtain tieline data. This information was needed for design purposes. Stephen and Stephen (10) show data for $\mathrm{KF}$ and $\mathrm{Na}_{2} \mathrm{SO}_{4}$ with various alcohols. Figure 12 shows three alcohol/water/KF systems. As can be seen from this diagram, the alcohol-rich section of the phase envelope for each alcohol lies in the same area. The curves extend to between 93 and 99 wt \% butanol. The salt content is less than $0.1 \mathrm{wt} \%$. It is also known that in the 1-butanol/ water system, there is a miscibility gap from 8 to 77 wt \% 1-butanol. With this information, using the trends observed, the 1-butanol-rich phase 1 ine for the KF system was approximated from 77 to 97 wt \% 1-butanol, with the salt concentration in this phase approximated as zero. It was observed, as shown for tertiary-butanol, that the last tieline reported extended from the salt solubility limit in water to the last alcohol-rich point. This trend was followed in estimating the last tieline for the 1-butanol/ water/KF system. Similar trends were observed for alcohol/water $/ \mathrm{Na}_{2} \mathrm{SO}_{4}$ systems (10). Therefore, the same assumptions were made. The data for these two systems were used to design various separations flowhseets.

\section{SEPARATION-PROCESS DESIGN}

\subsection{Design Variables and Assumptions}

A simplified flow diagram for the conventional 1950s process for solvent separations of the Clostridia fermentation product is shown in Fig. 13a (9). The products of the separation are dried-distillation solids (a nutritious cattle feed), water, and the purified alcohols. The focus of this study was solvent separations, but soljds separation was. also included to put all of the flowsheets on an equal basis.

The beer column, concentrating the feed to 50 wt \% solvents, serves two purposes. First, 96 wt \% of the feed stream is removed as pure water. Thus downstream columns have much lower flow rates than the beer column. Second, the beer still removes all the distiller's solids from the alcohol stream. To facilitate solids handling, a beer column has no reboiler; instead live steam is injected into the column to strip the alcohols from the water. The feed is added to the top plate, then 15 to 30 sieve trays, designed not to plug with solids, provide vaporliquid equilibrium contacting. Solids are filtered from the bottoms stream and spray-dried.

The overhead product ( 50 wt $\%$ alcohols) is fed into a column where the 2-propanol/water and ethanol/water azeotropes are separated from butanol and water. In a column not shown in Fig. 13a, the ethanol/water azeotrope is separated from the 2-propanol/water azeotrope. The butanol/ 


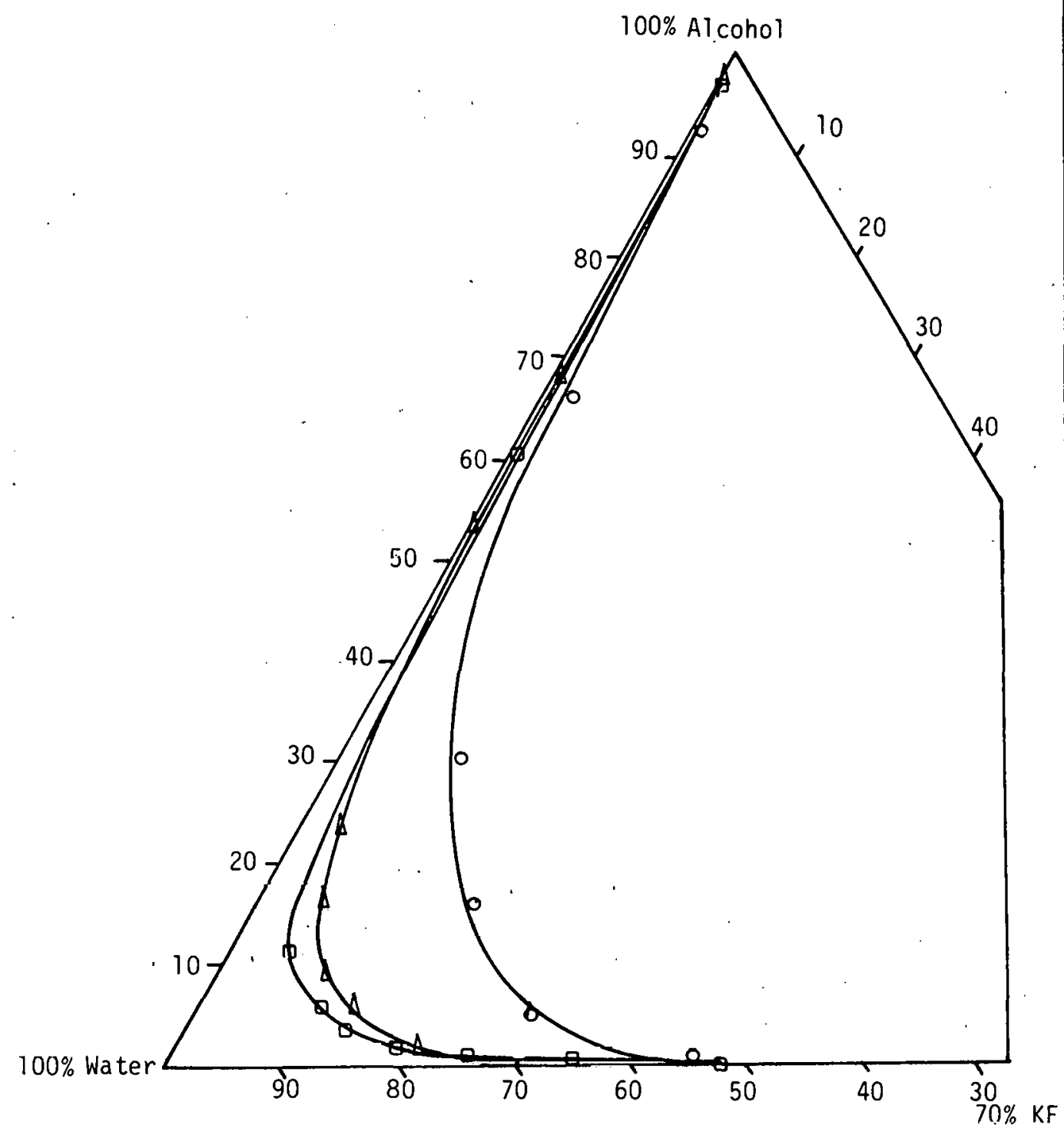

- Ethanol

$\Delta$ t-butanol

- 1-propanol
MASSACHUSETTS INSTITUTE OF TECHNOLOGY SCHOOL OF CHEMICAL ENGINEERING PRACTICE OAK RIDGE NATIONAAL LABORATORY

ALCOHOL TREND IN

ALCOHOL/WATER/KF SYSTEMS (10) 

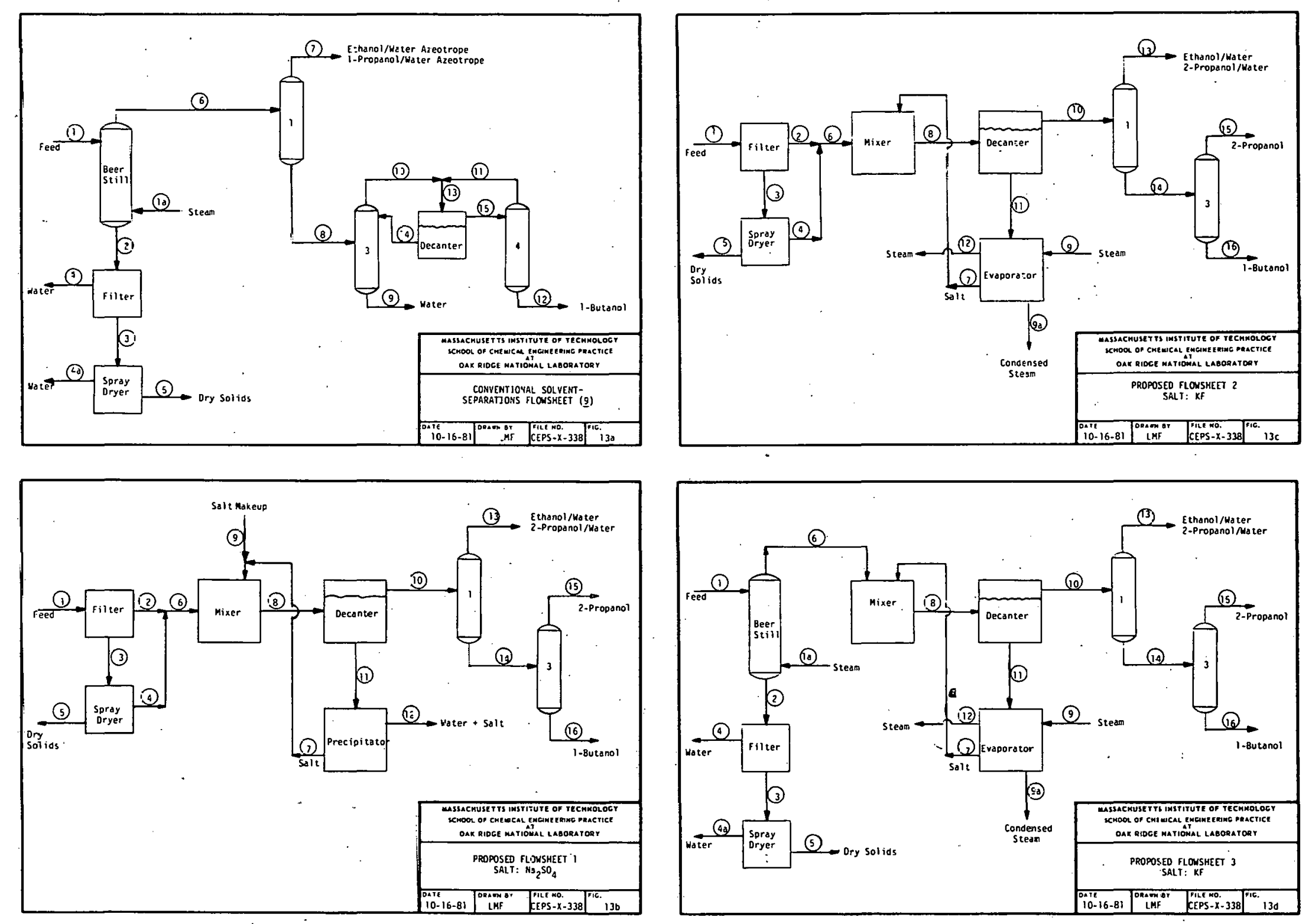
water azeotrope is separated in the last two columns, taking advantage of the miscibility gap to cross the azeotrope as discussed in Sect. 2.1 and Fig. 3. The butanol/water azeotrope from the top of columns 3 and 4 enters a decanter, from which the separated butanol-rich phase is fed into column 4, and the water-rich phase is recycled to column 3 . Purified butanol is removed from the bottom of column 4 .

Three alternative schemes were proposed and evaluated in which salt was added to the solvent stream to effect the alcohol/water separations and to reduce the downstream processing. These designs were based on the butanol/water/salt data obtained experimentally. The design variables are 1 isted in Table 1. The feed composition is similar to actual fermentation broth compositions produced by Clostridia strain acmylosaccharobutylpropylicum (11).

Table 1. Design Variables

Feed Composition: $\quad 2$ wt $\%$ solvents, 98 wt \% water

Solvent Composition: 70 wt \% 1-butanol, 27 wt \% 2-propanol, 3 wt \% ethanol

Plant Capacity: $\quad 150 \times 10^{6} \mathrm{~kg} / \mathrm{y}$ neutral solvents product

Assumptions: $\quad 95$ wt $\%$ recovery of solvents

99.5 mole \% purity of products

ethanol/water and 2-propanol/water azeotropes produced but not separated

335 day/y plant operation

\subsection{Process-Design Results}

\subsubsection{Flowsheet Descriptions}

Three alternative separation flowsheets were designed (Figs. $13 \mathrm{~b}, 13 \mathrm{c}$, and 13d) in addition to the conventional process. A1] four processes have a filter and spray dryer of equal size to concentrate and dry the solids. The feed to column 1 (from the decanter) is 97 wt \% alcohol and 3.wt \% water for the three proposedprocesses; it is 50 wt \% alcohol, 50 wt \% water (from the beer column) for the conventional process. The overhead product from column 1 is a mixture of the 2-propanol/ water and ethanol/water azeotropes. The separation of the azeotropes is the same as for the conventional process and therefore was not included in this comparison. The design of columns 1 and 3 are the same for the three processes.

Flowsheet 1 (Fig. 13b) uses sodium sulfate $\left(\mathrm{Na}_{2} \mathrm{SO}_{4}\right)$ as the salt. It was designed to exploit the water solubility characteristics of $\mathrm{Na}_{2} \mathrm{SO}_{4}$; 
the solubility changes significantly with changes in temperature $(4.50$ wt $\%$ at $0.7^{\circ} \mathrm{C}$ to $16.3 \mathrm{wt} \%$ at $20^{\circ} \mathrm{C}$; see Appendix 9.1 for more details). A precipitator with refrigeration was used to precipitate most of the salt for recycling back to the mixer. The salt that remained soluble in the water was discharged as a waste stream. (Due to the preliminary nature of this project, the disposal problem and cost was not considered.)

Potassium fluoride (KF) was the salt used in Flowsheet 2. (Fig. 13c). A multiple-effect evaporator was designed to evaporate all the water and yield solid salt to be recycled to the mixer. The steam discharged from the evaporator was not re-used in this process. More salt had to be used to effect the separation than for flowsheet 1, resulting in a larger mixer and decanter.

Potassium fluoride was also used in Flowsheet 3 . A beer still was used to remove most of the water. However, approximately $3 \%$ of the butanol was lost with the bottoms stream from this column. A multiple-effect evaporator was used to concentrate the salt to be recycled.

\subsubsection{Equipment Sizing and Costing}

In designing the beer still and all distillation columns, it was assumed that a binary separation was performed between light key-heavy key components. A reflux ratio $R$ of $1.2 R_{\min }$ was used with a McCabe-Thiele analysis to determine the number of stages. The temperatures at the top and bottom of the columns were assumed to be the approximate bubble points of the outlet streams. The Brown-Souders flooding velocity correlation (12) was used to calculate column diameters from the tray area required. A sample calculation is shown in Appendix 9.2.1.

A horizontal-belt filter was chosen to filter the distiller's solids, because it is operated continuously and is principally used for the dewatering and washing of coarse substances (13). A belt speed and cake thickness were assumed to calculate the filtering area required for the given solids feed rate. A sample calculation is given in Appendix 9.2.2.

A spray dryer was used to completely dry the distiller's solids and to remove all traces of alcohol. One of the major and most successful applications of spray dryers is for solutions, slurries, or pastes which cannot be dewatered mechanically (12). Since the solids in this process are absorbent, they fall into this category. The size and cost of a spray dryer is dependent on its evaporative capacity, as shown in Appendix 9.2.3.

The alcohol/water separation was achieved in a mixer-settler system. The salt is added to the alcohol/water mixture in a stainless steel mixing tank with an agitator. The solution then flows to a settler or decanter, where it is separated by gravity flow, after splitting into two phases. Both the mixing tank and settling tank were sized volumetrically for a given residence time (see Appendix 9.2.4). 
The phase separation achieved and the relative quantities of the phases were determined from the experimental data. The amount of salt added and the composition of the phases can be calculated with the phase diagram if the flow rates are known. Figure 14a shows the 1-butanol/water/ $\mathrm{Na}_{2} \mathrm{SO}_{4}$ system used for Flowsheet 1. Line $A B$ is the tieline used; point $A$ represents the composition of the butanol-rich phase (97\% butanol/3\% water $/ 0 \%$ $\left.\mathrm{Na}_{2} \mathrm{SO}_{4}\right)$; and point $\mathrm{B}$ represents the composition of the water-rich $(0 \% /$ $81.4 \% / 18.6 \%$ ) phase. Line ab is the operating line. Point 1 represents the mixture point $(1.6 \% / 80.1 \% / 18.3 \%)$. Line segment $B-1$ is the relative amount of the butanol-rich phase $(B-1 / A B)$ and line segment $1-A$ is the relative amount of the water-rich phase (1-A/AB). Figure $14 \mathrm{~b}$ shows the 1-butanol/water/KF system used for Flowsheets 2 and 3 (Figs. 13c and 13d). Line $C D$ is the tieline used for both flowsheets; point $C$ is located at $97 \%$ butanol $/ 3 \%$ water $/ 0 \% \mathrm{KF}$ and point $\mathrm{D}$ is at $0 \%$ butanol $/ 50.6 \%$ water $/ 49.4 \%$ KF. Line cd is the operating line for Flowsheet 2 . Point 2 represents the mixture point $(1 \% / 50 \% / 49 \%)$.

Line segment $D-2$ is the relative amount of the butanol-rich phase, and 1 ine segment $2-C$ is the relative amount of the water-rich phase. Line ed is the operating 1 ine for Flowsheet 3 . Point 3 represents the mixture point $(34 \% / 34 \% / 32 \%)$. Line segment $D-3$ is the relative amount of the butanol-rich phase, and line segment $3-C$ is the relative amount of the water-rich phase.

The cost of the refrigeration system used in Flowsheet 1 (Fig. 13b) was based on its refrigeration capacity, calculated from the mass flow rate into the system and the temperature drop required to precipitate the maximum amount of salt. The temperature drop was $21^{\circ} \mathrm{C}$, and $79.4 \%$ of the salt precipitated. A sample calculation is in Appendix 9.2.5.

A multiple-effect evaporator was used in Flowsheets 2 and 3 . The evaporators were sized using a simplified method developed by Coates (14). To use this method, the temperature of the feed stream, temperature of the vapor in the last effect, the overall heat transfer coefficient, and the number of effects had to be specified. A sample calculation is shown in Appendix 9.2.6.

Condensers and reboilers were modeled as heat exchangers, with the heat duty calculated assuming ideal solution behavior. Tower coolingwater entering at $20^{\circ} \mathrm{C}$ and exiting at $40^{\circ} \mathrm{C}$ was used as the condensing medium; 100-psia steam provided heat to the reboilers. (see Appendix 9.2.7 for a sample calculation.)

The costing of each piece of equipment is shown in Appendix 9.2. Cost data were obtained from Peters and Timmerhaus (15). The prices obtained were adjusted to mid-1981 prices, using economic indicators $(\underline{16})$. 

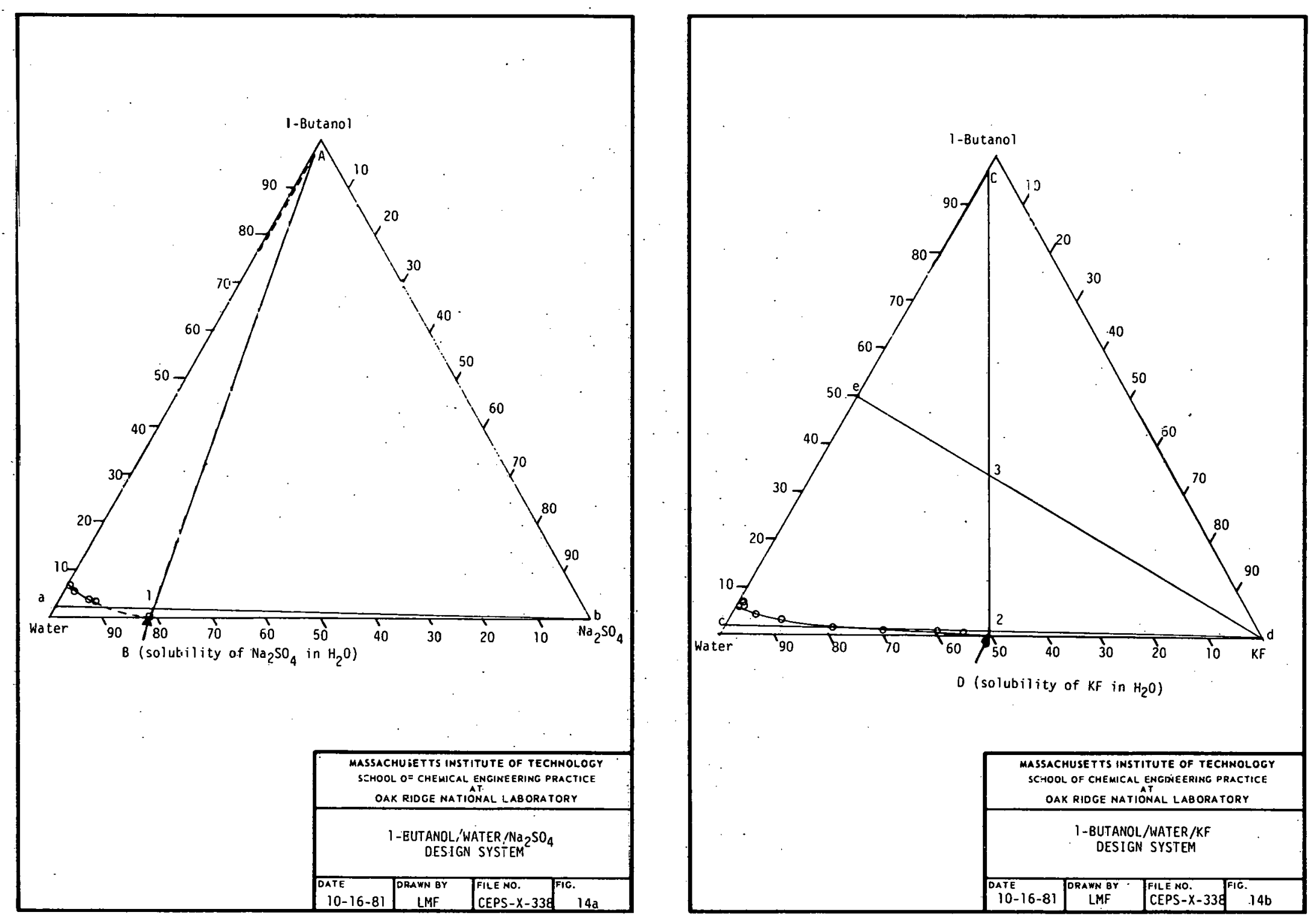

N 


\subsection{Overall Mass and Heat Balances}

The overall mass balances for the three proposed flowsheets and the conventional flowsheet are shown in Tables $2 a, 2 b, 2 c$, and $2 d$. The energy usage of each process is shown in Tables $3 a, 3 b, 3 c$, and $3 d$. The recovery of butanol ranged from $94.3 \%$ (conventional flowsheet) to $98.6 \%$ (Flowsheets 1 and 2 ), while the butanol purity was $99.9 \%$ for the conventional flowsheet and $99.6 \%$ for the three other flowsheets.

\section{COMPARISON OF PROPOSED PROCESSES WITH CONVENTIONAL PROCESS}

The four processes studied were compared on an incremental cost basis. Al1 equipment costs were purchase costs, except for the column trays and evaporators, which were installed costs. The capital costs of each process included equipment costs and the initial cost of the recyclable salt (Flowsheets 1,2, and 3). The only operating costs, estimated on a yearly basis, were the cost of utilities and of lost salt. Labor costs, insurance, taxes, overhead, and other operating costs were not included.

The capital costs and utilities costs for each of the four processes are shown in Table 4. Process equipment that was the same for all four processes was not considered, e.g., the column that separated the ethanol/ water and 2-propanol/water azeotropes. Also, a filter and spray dryer were added to the conventional process,.. so that all processes would yield similar products.

The capital costs for flowsheet 1 (Fig. 13b) are $\$ 4.26 \times 10^{6}$, with operating costs (utilities and salt makeup) of $\$ 1.65 \times 10 \% \mathrm{y}$. The two major operating costs for this process are the refrigeration and makeup salt needed to replace the salt lost in the precipitation process. Due to the huge expense involved for the salt makeup, it seems likely that additional processing equipment could be added to recover the salt and significantly cut the salt cost.

The capital costs for flowsheet 2 (Fig. 13c) are $\$ 2.25 \times 10^{6}$ with utilities costs of $\$ 4.76 \times 10^{6} / \mathrm{y}$. The one significant cost of this process is the multiple-effect evaporator and the steam needed for its operation. However, from the costs evaluated in this study, this process seems to be more economical than that shown in Flowsheet 1.

of the three alternative processes proposed, Flowsheet 3 had the lowest costs. The capital costs for this process were $\$ 1.72 \times 10^{6}$ with operating costs of $\$ 2.14 \times 10^{6} / \mathrm{y}$. The expense of a beer stili and a small multipleeffect evaporator was much less than that of a large multiple-effect evaporator (Flowsheet 2); while the design of this process involved using $\mathrm{KF}$ as the salt, $\mathrm{Na}_{2} \mathrm{SO}_{4}$ could also have been used. This wnuld have resulted in slightly lower costs, because of the smaller amount of $\mathrm{Na}_{2} \mathrm{SO}_{4}$ needed to effect the butanol/water separation and the lower cost of $\mathrm{Na}_{2} \mathrm{SO}_{4}$. 
Table 2. Overall Mass Balances

\begin{tabular}{|c|c|c|c|c|c|c|c|c|}
\hline \multirow[b]{2}{*}{ Component } & \multicolumn{2}{|c|}{ Streams in $(\mathrm{kg} / \mathrm{h})$} & \multicolumn{6}{|c|}{ Streams out $(\mathrm{kg} / \mathrm{h})$} \\
\hline & $7(1)$ & (1a) & (5) & (4) & (4a) & $(7)$ & $(9)^{-}$ & $(12)$ \\
\hline Water & 962,360 & 68,773 & 0 & 809,325 & 202,331 & 717 & 18,742 & 18. \\
\hline I-Butanol & 13,748 & 0 & 0 & 333 & 83 & 122 & 252 & 12,958 \\
\hline 2-Propanol & 5,303 & 0 & 0 & 0 & 0 & 5303 & 0 & ( \\
\hline Ethanol & 589 & 0 & 0 & 0 & 0 & 589 & 0 & 0 \\
\hline Solids & 19,804 & .0 & 19,804 & 0 & 0 & 0 & $\underline{0}$ & 0 \\
\hline Total & $1,001,804$ & 68,773 & 19,804 & 809,658 & 202,414 & 6731 & 18,994 & 12,976 \\
\hline
\end{tabular}

2b. Flowsheet 1 (Fig. 13b)

\begin{tabular}{|c|c|c|c|c|c|c|c|}
\hline \multirow[b]{2}{*}{ Component } & \multicolumn{2}{|c|}{ Streams In $(\mathrm{kg} / \mathrm{h})$} & \multicolumn{5}{|c|}{ Streams Out $(\mathrm{kg} / \mathrm{h})$} \\
\hline & (1) & (9) & $(5)$ & $(12)$ & $(13)$ & (15) & $(16)$ \\
\hline Wáler & 962,360 & 0 & 0 & 961,750 & 610 & 0 & 0 \\
\hline 1-Butanol & 13,748 & 0 & 0 & 0 & 65 & 133 & 13,550 \\
\hline 2-Propanol & 5,303 & 0 & 0 & 0 & 1143 & 4111 & 49 \\
\hline Ethanol & 589 & 0 & 0 & 0 & 589 & 0 & 0 \\
\hline Salt $\left(\mathrm{Na}_{2} \mathrm{SO}_{4}\right)$ & 0. & 45,318 & 0 & 45,318 & 0 & 0 & 0 \\
\hline Solids & 19,804 & 0 & 19,804 & 0 & 0 & 0 & 0 \\
\hline Total & $, 001,804$ & 45,318 & 19,804 & $1,007,068$ & 2407 & 4244 & 13,599 \\
\hline
\end{tabular}

2c. Flowsheet 2 (Fig. 13c)

\begin{tabular}{|c|c|c|c|c|c|c|c|c|}
\hline \multirow[b]{2}{*}{ Component } & \multirow{2}{*}{\multicolumn{2}{|c|}{$\frac{\text { Streams In }(\mathrm{kg} / \mathrm{h})}{(\mathrm{g})}$}} & \multicolumn{6}{|c|}{ Streams out $(\mathrm{kg} / \mathrm{h})$} \\
\hline & & & $(5)$ & $(12)$ & $(9 a)$ & $(13)$ & (15) & $(16)$ \\
\hline Water & 962,360 & 165,607 & 0 & 137,393 & 989,964 & 610 & 0 & 0 \\
\hline I-Butanol & 13,748 & 0 & 0 & 0 & 0 & 65 & 133 & 13,550 \\
\hline 2-Propanol & 5,303 & 0 & 0 & 0 & 0 & 1143 & 4111 & 49 \\
\hline Ethanol & 589 & 0 & 0 & 0 & 0 & .589 & 0 & 0 \\
\hline Salt (KF) & 0 & 0 & 0 & 0 & $\dot{0}$ & 0 & 0 & 0 \\
\hline Solids & 19,804 & 0 & 19,804 & 0 & 0 & 0 & 0 & 0 \\
\hline Total & $1,001,804$ & 165,607 & 19,804 & 137,393 & 989,964 & 2407 & 4244 & 13,599 \\
\hline
\end{tabular}

2d. Flowsheet 3 (Fig. 13d)

\begin{tabular}{|c|c|c|c|c|c|c|c|c|c|c|c|}
\hline \multirow[b]{2}{*}{ Component } & \multicolumn{3}{|c|}{ Streams In $(\mathrm{kg} / \mathrm{h})$} & \multicolumn{8}{|c|}{ Strpams nut $(\mathrm{kg} / \mathrm{h})$} \\
\hline & (1) & (1a) & (g) & $(5)^{2}$ & $(12)$ & $(9 a)$ & $(4)$ & $(4 a)^{2}$ & $(13)$ & $(15)$ & $(16)$ \\
\hline Water & 962,360 & 68,773 & 3179 & 0 & 2697 & 19,363 & 809,325 & 202,331 & 596 & 0 & 0 \\
\hline 1-Butanol & 13,748 & 0 & 0 & 0 & 0 & 0 & 333 & 83 & 64 & 133 & 13,135 \\
\hline 2-Propanol & 5,303 & 0 & 0 & 0 & 0 . & 0 & 0 & 0 & 1143 & 4111 & 49 \\
\hline Ethanol & 589 & 0 & 0 & 0 & 0 & 0 & 0 & 0 & 589 & 0 & 0 \\
\hline Salt (KF) & 0 & 0 & 0 & 0 & 0 & 0 & 0 & 0 & 0 & 0 & 0 \\
\hline Solids & 19,804 & 0 & 0 & 19,804 & 0 & 0 & 0 & 0 & 0 & 0 & 0 \\
\hline Total & 001,804 & 68,773 & 3179 & 19,804 & 2697 & 19,363 & 809,658 & 202,414 & 2392 & 4244 & 13,184 \\
\hline
\end{tabular}


Table 3. Energy Usage

3a. Conventional Flowsheet (Fig. 13a)

Equipment

Beer Still

Column 1-Condenser

Column 1-Reboiler Column 3,4-Condenser Column 3-Reboiler Column 3-Reboiler Steam $(\mathrm{kg} / \mathrm{h})$

68,773 (exhaust steam)

$2.39 \times 10^{4}(100 \mathrm{psia})$

$6.34 \times 10^{4}(100 \mathrm{psia})$

$3.41 \times 10^{4}$ (100 psia)
Cooling Water $(\mathrm{kg} / \mathrm{h})$

$8.48 \times 10^{4}\left(20^{\circ} \mathrm{C}\right)$

$3.09 \times 10^{5}\left(20^{\circ} \mathrm{C}\right)$

3b. Flowsheet 1 (Fig. 13b)

Precipitator

Column 1-Condenser

Column 1-Reboiler

Column 3-Condenser

Column 3-Reboiler

3c. Flowsheet 2 (Fig. 13c)

Evaporator

$1.66 \times 10^{5}$ (70 psia)

Column 1-Condenser

Column 1-Reboiler

7799 (100 psia)

Column 3-Condenser

Column 3-Reboiler

$2.95 \times 10^{4}(100 \mathrm{psia})$

3d. Flowsheet 3 (Fig. 13d)

Beer SLill

Evaporator

Column 1-Condenser

Column 1-Reboiler

Column 3-Condenser

Column 3-Reboller
68,773 (exhaust steam)

3179 (70 psia)

7799 (100 psia)

$2.95 \times 10^{4}(100$ psia $)$
$2.26 \times 10^{4}\left(20^{\circ} \mathrm{C}\right)$

$9.55 \times 10^{4}\left(20^{\circ} \mathrm{C}\right)$
$2.26 \times 10^{4}\left(20^{\circ} \mathrm{C}\right)$

$9.55 \times 10^{4}\left(20^{\circ} \mathrm{C}\right)$

$9.86 \times 10^{7}\left(\Delta T=21^{\circ} \mathrm{C}\right)$
Refrigeration (Btu/h) 
Tatle 4. Capital and Utilities Costs for Conventional Process and the Three Proposed Alternative Processes

\begin{tabular}{|c|c|c|c|c|c|c|c|c|}
\hline \multirow[b]{2}{*}{ Equipment } & \multicolumn{2}{|c|}{ Flowsheet 1} & \multicolumn{2}{|c|}{ Flowsheet 2} & \multicolumn{2}{|c|}{ Flowsheet 3} & \multirow{2}{*}{$\begin{array}{l}\text { Lonventional } \\
\text { Capital } \\
\text { Cost } \\
(\$) \\
\end{array}$} & \multirow{2}{*}{$\begin{array}{l}\text { Flowsheet } \\
\text { Utilities } \\
\text { Cost } \\
(\$ / y) \\
\end{array}$} \\
\hline & $\begin{array}{l}\text { Capital } \\
\text { Cost } \\
(\$) \\
\end{array}$ & $\begin{array}{l}\text { Utilities } \\
\text { Cost } \\
(\$ / y) \\
\end{array}$ & $\begin{array}{l}\text { Capital } \\
\text { Cost } \\
(\$) \\
\end{array}$ & $\begin{array}{l}\text { Utilities } \\
\text { Cost } \\
(\$ / y) \\
\end{array}$ & $\begin{array}{l}\text { Capital } \\
\text { Cost } \\
(\$) \\
\end{array}$ & $\begin{array}{l}\text { Utilities } \\
\text { Cost } \\
(\$ / y) \\
\end{array}$ & & \\
\hline Filter & 17,585 & - & 17,585 & - & 17,585 & - & 17,585 & - \\
\hline Spray Dryer & $1,217,470$ & - & $1,217,470$ & - & $1,217,470$ & - & $1,217,470$ & - \\
\hline Mixer & 94,695 & - & 108,220 & - & 18,940 & - & - & - \\
\hline ['ecanter & 70,345 & - & 82,520 & - & 14,205 & - & 5,415 & - \\
\hline Frecipitator/Refrigeration & $2,705,490$ & $4,656,206$ & - & - & - & - & - & - \\
\hline Evaporator & - & - & 432,880 & $3,528,330$ & 51,405 & 67,554 & - & - \\
\hline $\begin{aligned} \text { Columns } 3 \& & 4 \text {-Column } \\
& \text {-Trays } \\
& \text {-Condenser } \\
& \text {-Reboiler }\end{aligned}$ & $\begin{array}{r}41,935 \\
9,740 \\
18,265 \\
13,395\end{array}$ & $\begin{array}{r}- \\
\overline{-}, 354 \\
940,826\end{array}$ & $\begin{array}{r}41,935 \\
9,740 \\
18,265 \\
13,395\end{array}$ & $\begin{array}{l}- \\
24,354 \\
940,326\end{array}$ & $\begin{array}{r}41,935 \\
9,740 \\
18,265 \\
13,395\end{array}$ & $\begin{array}{l}- \\
24,354 \\
940,826\end{array}$ & $\begin{array}{r}100,105 \\
6,500 \\
40,180 \\
42,615\end{array}$ & $\begin{array}{r}- \\
\overline{-}, 861 \\
3,109,510\end{array}$ \\
\hline $\begin{array}{l}\text { Salt-Inventory (see Sect.9.2.4) } \\
\text {-Makeup } \\
\text {-Loss ( } 5 \% \text { of total }\end{array}$ & $\begin{array}{c}12,746 \\
- \\
-\end{array}$ & $\begin{array}{r}- \\
159,515,370 \\
637 \\
\end{array}$ & $\begin{array}{c}245 ; 622 \\
- \\
-\end{array}$ & $\overline{-}-$ & $\begin{array}{l}4,741 \\
- \\
-\end{array}$ & $\begin{array}{l}- \\
- \\
.237\end{array}$ & $\begin{array}{l}- \\
- \\
-\end{array}$ & $\begin{array}{l}- \\
-\end{array}$ \\
\hline & $4,262,031$ & $165,391,953$ & $2,247,997$ & $4,760,351$ & $1,718,311$ & $2,144,760$ & $1,761,845$ & $4,829,478$ \\
\hline
\end{tabular}


Since Flowsheet 3 was the best of the proposed processes, it was compared with the conventional process. The capital costs for the conventional process were $\$ 1.76 \times 10^{6}$, and the utilities costs were $\$ 4.83 \times 10^{6} / \mathrm{y}$. The capital costs for these two processes were very similar. However, the utilities costs for the conventional process were greater by a factor of 2.25. This difference was due to the larger boilup rates required in the columns following the beer still in the conventional process.

\section{CONCLUSIONS}

1. The best of the three new separation designs uses a beer still to concentrate the feed to 50 wt \% solvents, KF salt, and a multipleeffect evaporator for salt recovery. This process has comparable incremental capital costs $\left(\$ 1.72 \times 10^{6}\right.$ vs $\left.\$ 1,76 \times 10^{6}\right)$ and much more favorable incremental operating costs $\left(\$ 2.14 \times 10^{6} / \mathrm{y}\right.$ vs $\left.\$ 4.83 \times 10^{6} / \mathrm{y}\right)$ than the conventional separation.

2. $\mathrm{Na}_{2} \mathrm{SO}_{4}$, the best salt for this process, effected good phase separation, while its low water solubility means a low salt addition rate. Addition of this salt can break both the butanol/water and the propanoil/ water azeotropes.

3. Evaporation is better than precipitation for salt recovery in this process, because of the low salt losses and much lower energy requirements compared with precipitation.

\section{RECOMMENDATIONS}

1. The use of salt to separate alcohol/water mixtures is effective, and further investigation is definitely recommended.

2. For the Clostridia fermentation-product separation specifically, a parameteric study should be performed to optimize the separation design presented here.

3. The use of this process in other organic-aqueous separations should be investigated.

\section{ACKNOWLEDGMENTS}

We thank Terry Donaldson and $\mathrm{Cl}$ iff Brown for their ideas, suggestions, and support throughout the project. We also thank Gerry Strandberg for his help with the gas chromatograph and our analytical technique. 


\section{APPENDIX}

\subsection{Physical Properties}

Mixture and pure-component properties used in the distillation design calculations are 1isted for 1-butanol, 2-propanol, ethanol, and water in Tables 5. through 9.

Table 5. Azeotropic Compositions (19)

\begin{tabular}{lcc}
\hline & pressure $=101.325 \mathrm{kPa}$ & \\
\hline System & $\frac{\text { Mole } \%}{\vdots}$ & Temperature $\left({ }^{\circ} \mathrm{C}\right)$ \\
\hline 1-butanol water & $25.00 / 75.00$ & 92.25 \\
2-propanol/water & $68.54 / 31.46$ & 80.37 \\
Ethanol/water & $89.43 / 10.57$ & 78.15 \\
\hline
\end{tabular}

Table 6. Boiling Points $(\underline{19}, \underline{20})$

\begin{tabular}{lc}
\multicolumn{1}{c}{ Component } & Temperature $\left({ }^{\circ} \mathrm{C}\right)$ \\
\cline { 2 - 2 } Ethanol/water azeotrope & 78.15 \\
Ethanol & 78.4 \\
2-propanol/water azeotrope & 80.37 \\
2-propanol & 82.5 \\
1-butanol/water azeotrope & 92.25 \\
Water & 100 \\
1-Butanol & 117 \\
\hline
\end{tabular}


Table 7. Pure-Component Properties at $25^{\circ} \mathrm{C}(\underline{20})$

\begin{tabular}{|c|c|c|c|}
\hline Component & Molecular Weight & Density $(\mathrm{g} / \mathrm{ml})$ & $\begin{array}{c}\text { Heat of } \\
\text { Vaporization }(\mathrm{KJ} / \mathrm{kg})\end{array}$ \\
\hline 1-butanol & 74 & 0.8098 & 591.2 \\
\hline 2-propanol & 61 & 0.7854 & 715.0 \\
\hline Ethanol & 46 & 0.7893 & 838.7 \\
\hline Water & 18 & 1.00 & 608.1 \\
\hline
\end{tabular}

Table 8. Potassium Fluoride Solubility in Water (10)

\begin{tabular}{cc}
\hline$\frac{\mathrm{t}\left({ }^{\circ} \mathrm{C}\right)}{0}$ & $\frac{\text { Weight \% of KF }}{30.90}$ \\
10 & 34.87 \\
20 & 48.70 \\
30 & 51.95 \\
40.2 & 58.08 \\
60 & 58.72 \\
80 & 60.01 \\
\hline
\end{tabular}

Table 9. Sodium Sulfate Solubility in Water (10)

\begin{tabular}{lc}
\hline$\frac{\mathrm{t}\left({ }^{\circ} \mathrm{C}\right)}{0.70}$ & $\frac{\text { Weight } \% \mathrm{Na}_{2} \mathrm{SO}_{4}}{.}$ \\
10 & 4.50 \\
20 & 8.3 \\
30 & 16.3 \\
40 & 29.0 \\
\hline
\end{tabular}




\subsection{Sample Calculations}

All sample calculations are done for Flowsheet 3 unless noted.

\subsubsection{Beer Still (Distillation Column)}

The following method was used to design all distillation columns. This calculation was made for the beer still in Flowsheet 3 .

Known: $X_{F}=0.005$ butanol

From: butanol/water

$X-Y$ diagram

$\gamma_{F}=0.1010$

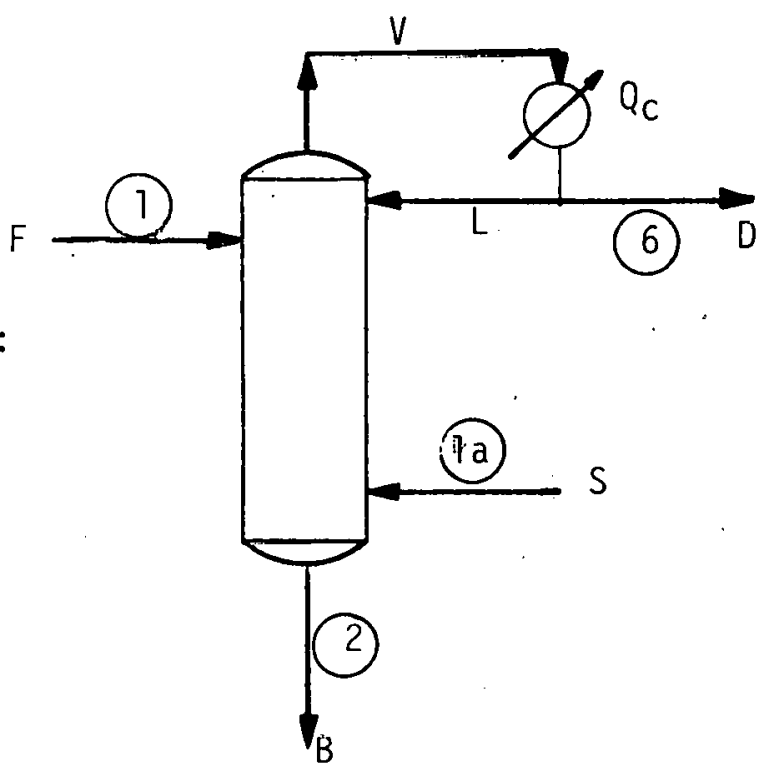

Assume the column distills up to:

$$
\begin{aligned}
& X_{D}=0.1957 \\
& Y_{D}=0.248
\end{aligned}
$$

Then the rectifying operating line for minimum reflux can be drawn, connecting the points $\left(X_{D}, Y_{D}\right)$ and $\left(X_{F}, Y_{F}\right)$.

$$
\begin{aligned}
& \text { slope }=\frac{0.248-0.101}{0.248-0.005}=0.605 \\
& \text { slope }=\left(\frac{L}{V}\right)_{\min }=\left(\frac{L}{L+D}\right)_{\min }=0.605 \\
& \frac{1}{0.605}=\left(\frac{L+D}{L}\right)_{\min }=1+\left(\frac{D}{L}\right)_{\min }=1+\frac{1}{R_{\min }}
\end{aligned}
$$

Therefore,

$$
R_{\min }=\left(\frac{L}{D}\right)_{\min }=1.532
$$

The actual reflux ratio used is $1.2 R_{\min }$ or 1.84 . Then, the new slope of the uperating line is 0.605 .

Next, material and enthalpy balances must be made around the column. overa11: $F+S=B+D$ 


$$
\begin{array}{ll}
\text { component: } & X_{F} F+X_{S} S=X_{B} B+X_{D} D \\
\text { (butanol) } & \\
\text { enthalpy: } & h_{f} F+h_{S} S=h_{B} B+h_{D} D+Q_{C}
\end{array}
$$

The feed $F$ is $53,729 \mathrm{kmol} / \mathrm{h}(982,000 \mathrm{~kg} / \mathrm{h} ; 98 \mathrm{wt} \%$ water, 2 wt \% butanol) total. Then assuming $98 \%$ 'recovery,

$$
\begin{aligned}
& X_{D} D=0.98 X_{F} F \\
& D=\frac{(0.98)(0.005)(53,729)}{0.1957}=1345.3 \mathrm{kmol} / \mathrm{hr}
\end{aligned}
$$

Then,

$$
\begin{aligned}
& \left(\frac{L}{D}\right)=1.84 \\
& L=1.84 D=1.84(1345.3)=2475.4 \mathrm{kmol} / \mathrm{h}
\end{aligned}
$$

and

$$
V=L+D=3820.7 \mathrm{kmol} / \mathrm{h}
$$

Next, if constant molal overflow, adiabatic operation, and constant $V$ throughout the column are assumed,

$$
S=V=3820.7 \mathrm{kmol} / \mathrm{h}
$$

The overall material balance is solved for $B$ :

$$
B=F+S-D=56,204.4 \mathrm{kmol} / \mathrm{h}
$$

The component mass balance is solved for $X_{B}$ :

$$
X_{B}=\frac{X_{F} F-X_{D} D}{B}=0.0001
$$

The specific enthalpies were calculated to be: 


$$
\begin{aligned}
& h_{F}=375.9 \mathrm{KJ} / \mathrm{kg} \\
& h_{S}=2670.0 \mathrm{KJ} / \mathrm{kg} \\
& h_{B}=418.0 \mathrm{~kJ} / \mathrm{kg} \\
& h_{D}=92.9 \mathrm{KJ} / \mathrm{kg}
\end{aligned}
$$

These values can be substituted into the enthalpy balance to calculate $Q_{C}$.

The number of stages required was found by a McCabe-Thiele analysis (see Fig. 15).

The beer still was sized using the Brown-Souders flooding velocity correlation, assuming an 18-in. tray spacing (12). The liquid flow rates and stream compositions are shown in Table 10.

Table 10. Beer-Column Stream Compositions

\begin{tabular}{lccrr}
\hline Component & $1(\mathrm{~kg} / \mathrm{h})$ & $\frac{1 \mathrm{a}(\mathrm{kg} / \mathrm{h})}{2(\mathrm{~kg} / \mathrm{h})}$ & $\frac{6(\mathrm{~kg} / \mathrm{h})}{\text { water }}$ \\
\cline { 2 - 3 } $\begin{array}{l}\text { butanol } \\
\text { propanol } \\
\text { ethanol }\end{array}$ & 962,360 & 68,773 & $1,011,656$ & 19,477 \\
total & 19,640 & 0 & -416 & 19,224 \\
\hline
\end{tabular}

For the rectifying section,

$$
\begin{aligned}
& L=30,072 \mathrm{~kg} / \mathrm{h}=66,158.5 \mathrm{lb} / \mathrm{h} \\
& V=68,773 \mathrm{~kg} / \mathrm{h}=151,300.61 \mathrm{~b} / \mathrm{h}
\end{aligned}
$$

The liquid and vapor densities were calculated using molar average densities and molecular weights:

$$
\begin{aligned}
& \rho_{L}=(0.503)(1)+(0.497)(0.8098)=0.9049 \mathrm{~kg} / 1=56.4 \mathrm{lb} / \mathrm{ft}^{3} \\
& \rho_{V}=\frac{[(0.503)(18)+(0.497)(74)]\left(492^{\circ} \mathrm{R}\right)}{\left(359 \mathrm{ft}^{3} / 1 \mathrm{bmole}\right)\left(650.4^{\circ} \mathrm{R}\right)}=0.0969 \mathrm{1b} / \mathrm{ft}^{3}
\end{aligned}
$$




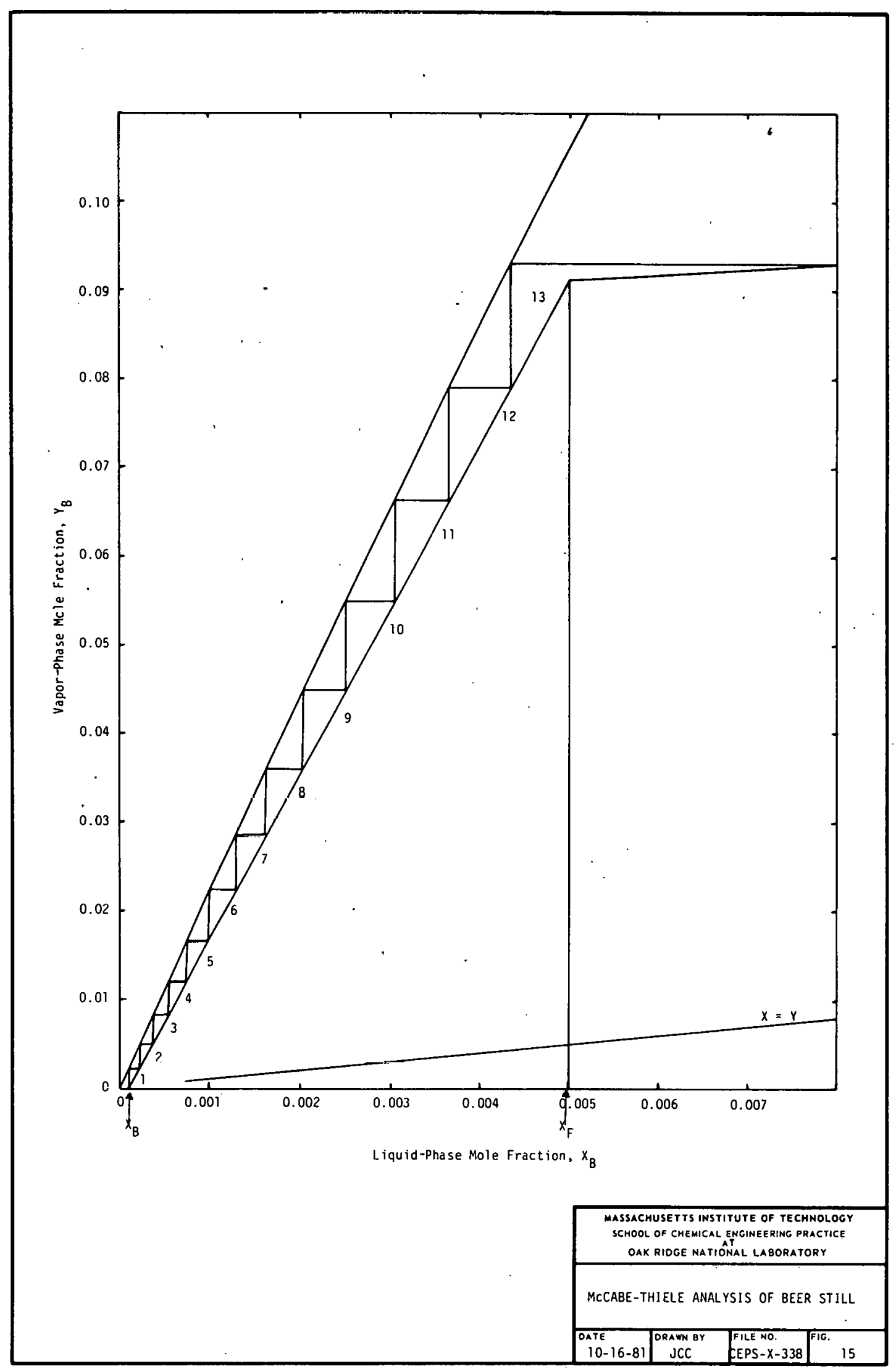


To use Fig. 18-10 (Perry's), $F_{1 v}$ is calculated from the following equation, where

$$
F_{1 V}=\frac{L}{V}\left(\frac{\rho_{V}}{\rho_{L}}\right)^{0.5}=\frac{66,158.4}{151,300.6}\left(\frac{0.0969}{56.4}\right)^{0.5}=0.018
$$
Then, if 18-in. tray spacing is assumed, $C_{s b}$ is read from Fig. 18-10 (12).
Therefore,

$$
\begin{aligned}
& C_{\text {sb }, \mathrm{flood}}=0.28=U_{n f}\left(\frac{20}{\sigma}\right)^{0.2}\left(\frac{\rho_{G}}{\rho_{L}-\rho_{G}}\right)^{0.5} \\
&=U_{n f}\left(\frac{20}{24}\right)^{0.2}\left(\frac{0.0969}{56.4-0.0969}\right)^{0.5} \\
& U_{n f}=7 \mathrm{ft} / \mathrm{s} \\
& U=0.85 U_{n f}=0.85(7)=5.95 \mathrm{ft} / \mathrm{s}
\end{aligned}
$$

The volumetric gas flow rate is:

$$
Q_{\max }=151,300.61 \mathrm{~b} / \mathrm{h}\left(1 / 0.0969 \mathrm{ft}^{3} / 1 \mathrm{~b}\right)(1 / 3600 \mathrm{~h} / \mathrm{s})=433.7 \mathrm{ft}^{3} / \mathrm{s}
$$

The column diameter can now be found:

$$
\begin{aligned}
& \frac{\pi D_{T}^{3}}{4} U=Q_{\max } \\
& \frac{\pi D_{T}^{3}}{4}(5.95)=433.7 \\
& D_{T}=9.6 \mathrm{ft} \text { or } 10 \mathrm{ft}
\end{aligned}
$$

This procedure is repeated for the stripping section of the column. 


$$
\begin{aligned}
& L=1,012,092 \mathrm{~kg} / \mathrm{h}=2,226,602.4 \mathrm{lb} / \mathrm{h} \\
& V=68,773 \mathrm{~kg} / \mathrm{h}=151,300.6 \mathrm{lb} / \mathrm{h} \\
& \rho_{L}=62.4 \mathrm{lb} / \mathrm{ft}^{3} \\
& \rho_{V}=\frac{18(492)}{359(672)}=0.0367 \mathrm{1b} / \mathrm{ft}^{3} \\
& F_{1 V}=\frac{L}{V}\left(\frac{\rho_{V}}{\rho_{L}}\right)^{0.5}=\frac{2,226,602.4}{151,300.6}\left(\frac{0.0367}{62.4}\right)^{0.5}=0.357
\end{aligned}
$$

If 18-in. tray spacing is assumed,

$$
\begin{aligned}
& C_{\text {sb,flood }}=0.17=U_{n f}\left(\frac{20}{\sigma}\right)^{0.2}\left(\frac{\rho_{G}}{\rho_{L}-\rho_{G}}\right)^{0.5} \\
& =U_{n f}\left(\frac{20}{24}\right)^{0.2}\left(\frac{0.0367}{62.4-0.0367}\right)^{0.5} \\
& U_{n f}=7.27 \mathrm{ft} / \mathrm{s} \\
& U=0.85 U_{n f}=0.85(7.27)=6.2 \mathrm{ft} / \mathrm{s} \\
& Q_{\max }=\frac{151,300.6}{(0.0367)(3600)}=1145 \mathrm{ft}^{3} / \mathrm{s} \\
& \frac{\pi D_{T}^{2}}{4} U=0 \\
& \frac{\pi D_{T}^{2}}{4}(6.2)=1145 \\
& D_{T}=15.3 \mathrm{ft} \text { or } 15.5 \mathrm{ft}
\end{aligned}
$$

Since this diameter is larger, it is taken as the design value. 
To: calculate the cost of the column, it was assumed to be made of carbon steel, with weight at approximately $34,000 \mathrm{1b}(15)$. From Peters and Timmerhaus (15), p. 768, the purchased cost is $\$ 50,000$. The column trays were assumed to be stainless steel sieve trays and were $75 \%$ efficient. For a 15.5 -ft-diam column (15):

$$
\begin{aligned}
& \text { installed cost }=\$ 4500 / \text { tray } \\
& \text { number of trays }=15 / 0.75=20 \\
& \text { installed cost }=\$ 90,000
\end{aligned}
$$

The steam needed for the beer still was $68,773 \mathrm{~kg} / \mathrm{h}$, as calculated earlier. The steam used was priced as exhaust steam (15). Therefore, the steam cost for this column is:

$$
S=68,773(\$ 0.50 / 1000 \mathrm{lb})=\$ 75.7 / \mathrm{h} \text { (1979 price) }
$$

\subsubsection{Horizontal-Belt Filter}

The following variables were chosen for operation of the filter:

$$
\begin{aligned}
& \text { belt speed }=50 \mathrm{ft} / \mathrm{min} \\
& \text { cake thickness }=6 \mathrm{in} . \\
& \text { Psolids. } 287.4 \mathrm{lb} / \mathrm{ft}^{3} .
\end{aligned}
$$

The amount of solids present in this system can be calculated from the yield of solvents and solids from the fermentation process (17).

One hundred lbs of invert molasses yields:

24 ib solvents

$17.7 \mathrm{lb}$ dry feed and $6.5 \mathrm{lb}$ protein $=24.2 \mathrm{lb}$ solids

Since $19,640 \mathrm{~kg} / \mathrm{h}$ of solvents are produced,

$$
\text { solids }=\left(\frac{24.2 \mathrm{lb} \text { solids }}{24 \mathrm{lb} \text { solvents }}\right)(19,640 \mathrm{~kg} / \mathrm{h} \text { solvents })=1.9,804 \mathrm{~kg} / \mathrm{h}
$$

For a solids feed rate of $19,804 \mathrm{~kg} / \mathrm{h}$,

$$
v_{\text {solids }}=\left(19,804 \frac{\mathrm{kg}}{\mathrm{h}}\right)\left(2.2 \frac{\mathrm{lb}}{\mathrm{kg}}\right)\left(\frac{1}{87.4} \frac{\mathrm{ft}^{3}}{1 \mathrm{~b}}\right)=500 \mathrm{ft}^{3} / \mathrm{h}
$$


Now we will determine the volume processed on a belt of unit width of one foot:

$$
(50 \mathrm{ft} / \mathrm{min})(60 \mathrm{~min} / \mathrm{h})(0.5 \mathrm{ft})(1 \mathrm{ft})=1500 \mathrm{ft}^{3} / \mathrm{h}
$$

and

$$
A=50 \mathrm{ft}(1 \mathrm{ft})=50 \mathrm{ft}^{2}
$$

Therefore, for the given solids feed rate,

$$
A \cdot=\frac{500}{1500}(50)=16.7 \mathrm{ft}^{2}
$$

For a filter unit of mild steel (14):

$$
\text { purchase cost }=\$ 13,000
$$

It is also assumed that the filter will remove $80 \%$ of the 1 iquid stream $(785,600 \mathrm{~kg} / \mathrm{h})$.

\subsubsection{Spray Dryer}

The feed to the spray dryer will contain $202,414 \mathrm{~kg} / \mathrm{h}$ of 1 iquids (water and butanol) and $19,804 \mathrm{~kg} / \mathrm{h}$ of solids. The evaporative capacity of the spray dryèr needed 15:

$$
202,414 \mathrm{~kg} / \mathrm{h}(2.2 \mathrm{lb} / \mathrm{kg})=445,311 \mathrm{lb} / \mathrm{h}
$$

For an 18-ft-diam spray dryer (15), the cost is $\$ 900,000$.

\subsubsection{Mixer-Decanter System}

The size of the salt stream (7) must be determined before the mixer and decanter can be sized. From Fig. 14b, it can be seen that the intersection point has the composition of $34 \%$ butanol $/ 32 \% \mathrm{KF} / 34 \%$ $\mathrm{H}_{2} \mathrm{O}$. The feed stream (6) contains $38,701 \mathrm{~kg} / \mathrm{h}$ and is $68 \%$ of the total feed to the decanter. Therefore,

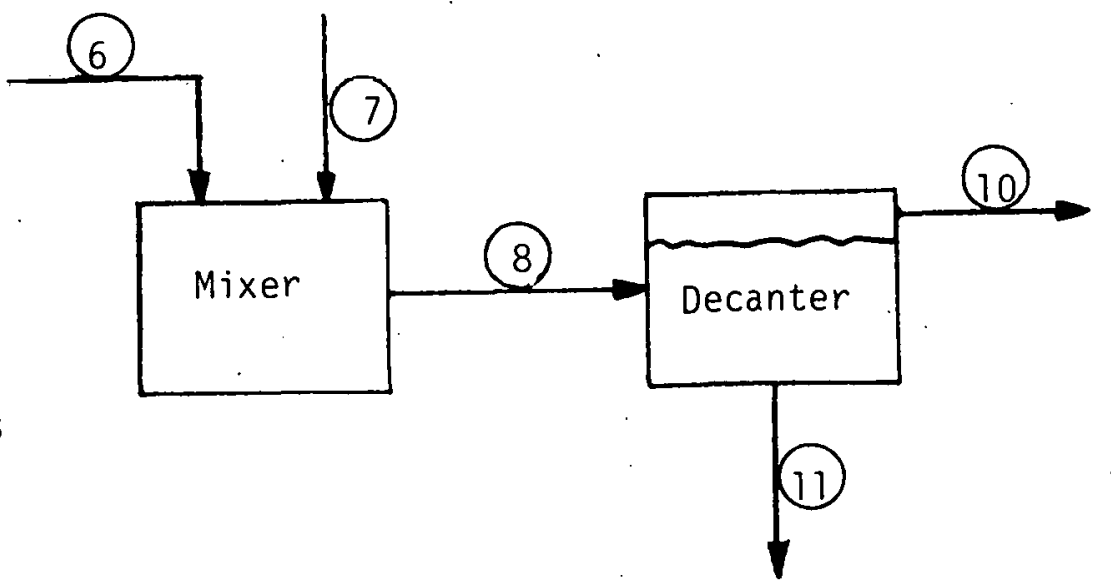




$$
\text { salt } \text { added }=(38,701 / 0.68)-38,701=18,212 \mathrm{~kg} / \mathrm{h}
$$

The volumetric flow into the mixer-decanter system can now be calculated:

Component Mass Flow $(\mathrm{kg} / \mathrm{h}) \quad \rho(\mathrm{kg} / \mathrm{l}) \quad$ Volumetric Flow $(1 / \mathrm{h})$

$\begin{array}{llll}\text { Water } & 19,477 & 19,477 .\end{array}$

$\begin{array}{llll}\text { Butanol } & 19,224 & 0.8098 & 23,739\end{array}$

$\begin{array}{clll}\text { Salt }(\text { KF }) & \frac{18,212}{56,913} & 2.48 & \frac{7,344}{50,560} \\ \text { Total } & 56,913 & & \end{array}$

Tank Vol, $V=(50,560 \mathrm{l} / \mathrm{h})(1.0567 / 4 \mathrm{gal} / 1)(1 / 60 \mathrm{~h} / \mathrm{min})(5 \mathrm{~min})=1113 \mathrm{gal}$ for $=1113 \operatorname{gal}(1 / 7.48)=149 \mathrm{ft}^{3}$

The following costs were found for 304-stainless steel vessels (15):

$$
\begin{aligned}
& \text { mixing tank: purchase cost }=\$ 14,000 \\
& \text { storage tank: purchase cost }=\$ 10,500
\end{aligned}
$$

The cost of the salt needed was also determined. The amount of salt needed initially, and to be continually recycled, was calculated for double the decanter residence time:

$$
\operatorname{salt}=18,212 \mathrm{~kg} / \mathrm{h}(1 / 60 \mathrm{~h} / \mathrm{min})(10 \mathrm{~min})=3035 \mathrm{~kg}
$$

Based on the current market price of $\mathrm{KF}(\underline{18})$ :

$$
\text { salt cost }=(3035 \mathrm{~kg})(2.2 \mathrm{lb} / \mathrm{kg})(\$ 0.71 / 1 \mathrm{~b})=\$ 4741
$$

If a $5 \%$ loss of salt during a year of operation is assumed, an additional operating cost will be involved:

$$
\text { makeup cost }=(\$ 4741)(0.05 / y)=\$ 237 / y
$$




\subsubsection{Precipitator}

This sample calculation is for flowsheet 1. The compositions of the exit streams from the precipitator can be calculated by knowing the feed stream composition and the solubility of $\mathrm{Na}_{2} \mathrm{SO}_{4}$. The precipitator will cool the stream from 22 to $0.7^{\circ} \mathrm{C}$ At these temperatures, the solubility of $\mathrm{Na}_{2} \mathrm{SO}_{4}$ is 18.6 and 4.5 wt \%, respectively.

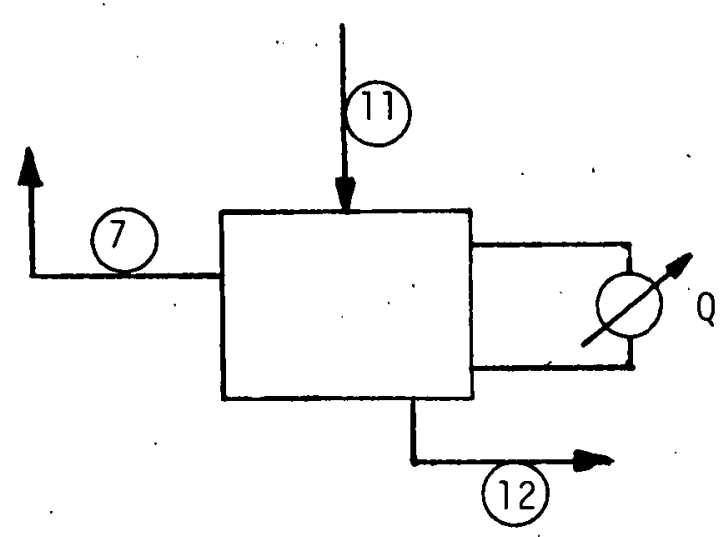

Component

Stream $(\mathrm{kg} / \mathrm{h})$

Water
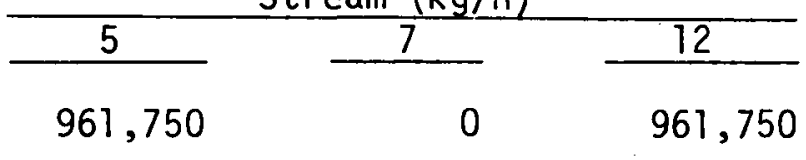

Salt

Total

$\frac{220,000}{1,181,750} \quad \frac{174,682}{174,682} \quad \frac{45,318}{1,007,068}$

To cost the refrigeration needed, we used:

$$
Q=\dot{m} C_{p} \Delta T
$$

where

$$
\begin{aligned}
\dot{\pi} & =\text { SLréall } 11 \\
C_{p} & =4.187 \mathrm{~kJ} / \mathrm{kg}-{ }^{\circ} \mathrm{C}\left(\mathrm{C}_{p} \text { for water }\right) \\
\Delta T & =22^{\circ} \mathrm{C}-1{ }^{\circ} \mathrm{C}=21^{\circ} \mathrm{C} \\
Q & =(1,181,750 \mathrm{~kg} / \mathrm{h})\left(4.187 \mathrm{~kJ} / \mathrm{kg}-{ }^{\circ} \mathrm{C}\right)\left(21^{\circ} \mathrm{C}\right) \\
& =\left(1.039 \times 10^{8} \mathrm{~kJ} / \mathrm{h}\right)(24 \mathrm{~h} / \mathrm{d})=\left(2.494 \times 10^{9} \mathrm{~kJ} / \mathrm{d}\right)(\mathrm{Btu} / 1.054 \mathrm{~kJ}) \\
& \left.=2.3662 \times 10^{9} \mathrm{Btu} / \mathrm{day}\right) . \\
Q & =\left(2.3662 \times 10^{9} \frac{\mathrm{Btu}}{\text { day }}\right)\left(\frac{1 \mathrm{ST} / \mathrm{D}}{288,000 \mathrm{Btu} / \text { day }}\right)=8.2 \times 10^{3} \mathrm{ST} / \mathrm{D}
\end{aligned}
$$

For this amount of refrigeration, capital cost is $\$ 2,000,000(15)$. The operating cost for refrigeration is (15): 


$$
\begin{array}{r}
\left(\frac{\$ 1.20}{288,000 \text { Btu }}\right)\left(2.3662 \times 10^{9} \frac{\mathrm{Btu}}{\text { day }}\right)=\$ 9859 / \text { day }(\text { or } \$ 411 / \mathrm{hr} \text { or } \\
\$ 3,304,440 / \mathrm{y})
\end{array}
$$

\subsubsection{Multiple-Effect Evaporator}

The multiple-effect evaporator was sized (heat transfer area, capacity, and steam consumption) using an approximate method developed by coates (13). The component mass balance is given as:

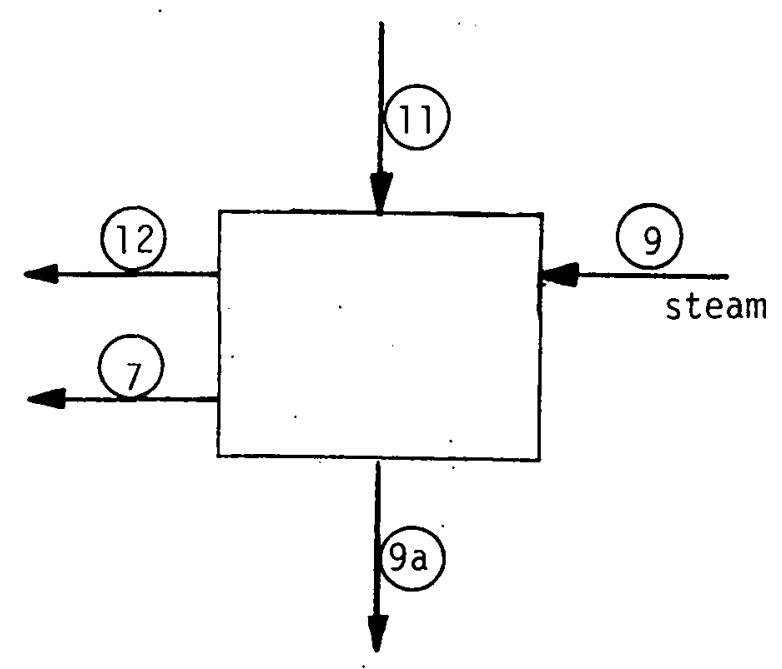

Component

Stream $(\mathrm{kg} / \mathrm{h})$

Water

$\frac{\text { Stream }(\mathrm{kg} / \mathrm{h})}{11} \frac{1}{12} \frac{7}{18,881}-0$

Salt (KF)

$\underline{18,212}$

$\frac{0}{18,881} \quad \frac{18,212}{18,212}$

Total 37,093

For the salt:

$$
\begin{aligned}
& \text { initial concentration }=49.5 \mathrm{wt} \% \text { salt }=\mathrm{N}_{f} \\
& \text { final concentration }=100 \mathrm{wt} \% \text { salt }=\mathrm{N}_{\mathrm{p}}
\end{aligned}
$$

We will do calculations for a seven-effect evaporator. To use this method, we assume:

1) negligible BPE (boiling point elevation)

2) $C_{p}=4.187 \mathrm{~kJ} / \mathrm{kg}-{ }^{\circ} \mathrm{C}$

3) $U_{1}=U_{2}=\ldots .=U_{7}=U$

$U \cong 10,200 \mathrm{~kJ} / \mathrm{h}-\mathrm{m}^{2}-{ }^{\circ} \mathrm{C} \quad\left(500 \mathrm{Btu} / \mathrm{h}-\mathrm{ft}^{2}-{ }^{\circ} \mathrm{F}\right)$ 
4) $A_{1}=A_{2}=\ldots=A_{7}=A$

A material balance is done:

$$
\begin{aligned}
& \text { feed: } \quad 37,093 \mathrm{~kg} / \mathrm{h} \\
& \text { product: } P=\frac{F N_{f}}{N_{p}}=37,093\left(\frac{0.495}{l}\right)=18,212 \mathrm{~kg} / \mathrm{h} \\
& \text { total evaporation: } \quad \Sigma E=F\left(\frac{N_{p}-N_{f}}{N_{p}}\right)=F-P \\
& =37,093-18,212=18,881 \mathrm{~kg} / \mathrm{h} \\
& E_{1}+E_{2}+\ldots+E_{7}=18,881 \mathrm{~kg} / \mathrm{h}
\end{aligned}
$$

The temperature (and therefore pressure) of the steam fed to the first effect and the vapor produced in the last effect are set.

Steam

$$
\begin{aligned}
& P_{S}=70 \text { psia } \\
& \mathrm{T}_{\mathrm{S}}=302.93^{\circ} \mathrm{F} \\
& \lambda_{\mathrm{s}}=907.9 \mathrm{Btu} / 1 \mathrm{~b} \\
& T_{S}=150.5^{\circ} \mathrm{C} \\
& \lambda_{S}=2107.4 \mathrm{~kJ} / \mathrm{kg}
\end{aligned}
$$

\section{Effect 7 (Last Effect)}

$$
\begin{aligned}
& P=1.5 \text { psia (3 in. } \mathrm{Hg}) \\
& T=113.9^{\circ} \mathrm{F}=45.5^{\circ} \mathrm{C}
\end{aligned}
$$

A11 latent heats of evaporation were found in Perry (11).

First, the temperature change in the first effect $\Delta_{l}$ must be calculated:

$$
\begin{aligned}
& \Sigma \Delta=150.5^{\circ} \mathrm{C}-45.5^{\circ} \mathrm{C}=105^{\circ} \mathrm{C} \\
& \frac{\Sigma \Delta}{\Delta_{1}}=1+\frac{U_{1} A_{1}}{U_{2} A_{2}}+\frac{U_{1} A_{1}}{U_{3} A_{3}}+\ldots+\frac{U_{1} A_{1}}{U_{7} A_{7}}=7
\end{aligned}
$$

and 


$$
\Delta_{1}=\frac{\Sigma \Delta}{n}=\frac{\sum \Delta}{7}=\frac{105}{7}=15^{\circ} \mathrm{C}
$$

The temperature and latent heat of vaporization in the first effect can be found:

$$
\begin{aligned}
& t_{L_{1}}=150.5-15=135.5^{\circ} \mathrm{C} \text { or } 275.90^{\circ} \mathrm{F} \\
& \lambda_{L_{1}}=927.5 \text { Btu/1b or } 2152.8 \mathrm{~kJ} / \mathrm{kg}
\end{aligned}
$$

Now the "average latent heat" is estimated:

$$
\begin{aligned}
b & =1+0.1(n)=1+0.1(7)=1.7 \\
\lambda_{a v} & =\frac{F C_{F}\left(t_{L_{1}}-t_{F}\right)}{\Sigma E}+\frac{\lambda_{L_{1}}}{b} \\
& =\frac{37,093(4.187)(135.5-22)}{18,881}+\frac{2152.8}{1.7} \\
& =933.6+1266.4=2200 \mathrm{~kJ} / \mathrm{kg}
\end{aligned}
$$

Next the average heat transfer coefficient is found:

$$
u_{a v}=\frac{U_{1}}{1+\frac{U_{1}}{U_{2}}+\frac{U_{1}}{U_{3}}+\ldots+\frac{U_{1}}{U_{7}}}=\frac{10,200}{7}=1457 \mathrm{~kJ} / \mathrm{h}-\mathrm{m}^{2}-{ }^{\circ} \mathrm{C}
$$

If $U_{a v}$ is used, the total area and area of each effect can be calculated:

$$
\begin{aligned}
& \Sigma A=\frac{\lambda_{a v} \Sigma E}{U_{a v} \Sigma \Delta}=\frac{2200(18,881)}{1457(105)}=272 \mathrm{~m}^{2} \\
& A_{1}-A_{2}=\ldots .=A_{7}=A=\frac{272}{7}=39 \mathrm{~m}^{2}
\end{aligned}
$$

The heat transfer rate is also calculated: 


$$
\begin{aligned}
q_{1} & =\Sigma E\left[\lambda_{a v}-\left(\frac{n-1}{n}\right) \lambda_{L}\right]=18,881\left[2200-\left(\frac{6}{7}\right) 2152.8\right] \\
& =6.70 \times 10^{6} \mathrm{~kJ} / \mathrm{h}
\end{aligned}
$$

If $q_{1}$ is used, the steam consumption can be found:

$$
S=\frac{9_{1}}{\lambda_{S}}=\frac{6.70 \times 10^{6}}{2107.4}=3179 \mathrm{~kg} / \mathrm{h}
$$

The steam economy can be calculated using the steam consumption:

$$
\text { economy }=\frac{\sum E}{S}=\frac{18,881}{3179}=5.9
$$

The evaporator is sized and costed according to the total heat transfer area (15):

$$
\begin{aligned}
& \Sigma A=2.72 \times 10^{2} \mathrm{~m}^{2} \\
& \text { installed cost }=\$ 38,000 \text { (for horizontal tubes) }
\end{aligned}
$$

The steam cost for 70 psia steam was estimated as that for 100 psig steam

\begin{tabular}{|c|c|c|}
\hline Component & $\begin{array}{l}\text { Flow Rate } \\
(\mathrm{kg} / \mathrm{h})\end{array}$ & $\begin{array}{l}\Delta H_{\mathrm{vap}} \\
(\mathrm{J} / \mathrm{kg})\end{array}$ \\
\hline Water & 34,593 & $6.081 \times 10^{2}$ \\
\hline Butan & $\underline{34,180}$ & $5.912 \times 10^{2}$ \\
\hline Total & 68,773 & \\
\hline
\end{tabular}
(14):

$$
S=3179 \mathrm{~kg} / \mathrm{h}(\$ 1.00 / 1000 \mathrm{lb})(2.2 \mathrm{lb} / \mathrm{kg})=\$ 6.99 / \mathrm{h} \text { or } \$ 56,000 / \mathrm{y}
$$

\subsubsection{Beer-Sti11 Condenser}

The condenser was modeled as a heat exchanger. The vapor mass balance is:

For a countercurrent flow heat exchanger, the stream temperatures are:

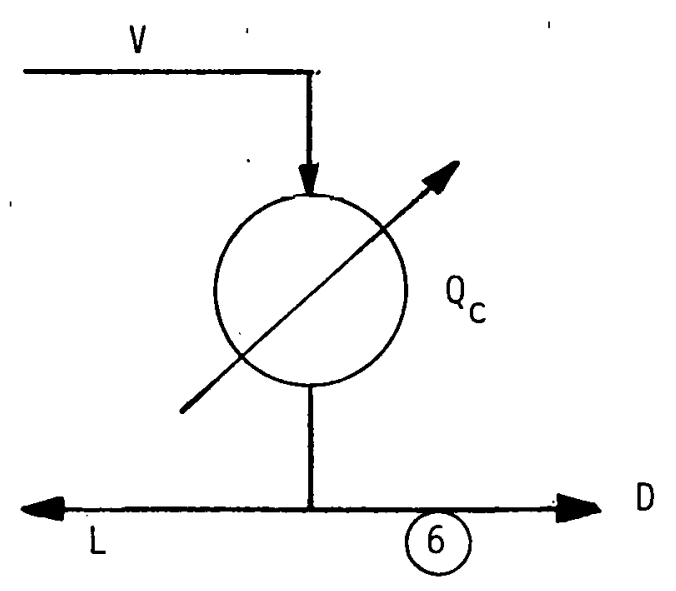




$$
\begin{array}{ll}
T_{h a}=88^{\circ} \mathrm{C} & T_{c a}=20^{\circ} \mathrm{C} \\
T_{h b}=22^{\circ} \mathrm{C} & T_{c b}=40^{\circ} \mathrm{C}
\end{array}
$$

The heat duty of the condenser and the corresponding cooling water requirement are:

$$
\begin{aligned}
& Q=34,593 \mathrm{~kg} / \mathrm{h}(608.1 \mathrm{~kJ} / \mathrm{kg})+34,180(591.2)=4.12 \times 10^{7} \mathrm{~kJ} / \mathrm{h} \\
& W=\frac{Q}{C_{p} \Delta \mathrm{T}}=\frac{4.12 \times 10^{7} \mathrm{~kJ} / \mathrm{h}}{4.187 \mathrm{~kJ} / \mathrm{kg}^{\circ} \mathrm{C}\left(20^{\circ} \mathrm{C}\right)}=4.92 \times 10^{5} \mathrm{~kg} / \mathrm{h}
\end{aligned}
$$

The condenser area can be calculated from the relationship:

$$
Q=U A \Delta T_{1 m}
$$

where

$$
\Delta \mathrm{T}_{1 \mathrm{~m}}=\frac{(88-40)-(22-20)}{\ln \frac{(88-40)}{(22-20)}}=14.5^{\circ} \mathrm{C}
$$

and

$$
U=3.066 \times 10^{3} \mathrm{~kJ} / \mathrm{m}^{2}-\mathrm{h}-{ }^{\circ} \mathrm{C}
$$

Therefore,

$$
A=\frac{4.12 \times 10^{7} \mathrm{~kJ} / \mathrm{h}}{\left(3.066 \times 10^{3} \mathrm{~kJ} / \mathrm{m}^{2}-\mathrm{h}-{ }^{\circ} \mathrm{C}\right)\left(14.5^{\circ} \mathrm{C}\right)}=927 \mathrm{~m}^{2}=9978 \mathrm{ft}^{2}
$$

Fixed-tube sheets will be used at $1 \mathrm{~atm}$. The price is based on $90 \%$ of the cost for floating-heads (15):

$$
\text { purchase cost }=(0.90)(\$ 50,000)=\$ 45,000
$$

The cost for cooling water is (15):

$$
\begin{aligned}
W & =\left(4.92 \times 10^{5} \mathrm{~kg} / \mathrm{h}\right)(\$ 0.10 / 1000 \mathrm{gal})(1 / 3.785 \mathrm{gal} / 1)(1 / 1 \mathrm{l} / \mathrm{kg}) \\
& =\$ 13 / \mathrm{h} \text { or } \$ 104,520 / \mathrm{y}
\end{aligned}
$$




\subsection{Nomenclature}
A
heat transfer area or filter-press area, $\mathrm{m}^{2}, \mathrm{ft}^{2}$
b
correction factor for latent heat
B
bottoms rate, $\mathrm{kmol} / \mathrm{h}$
$\mathrm{C}_{\mathrm{p}}$
heat capacity, $\mathrm{kJ} / \mathrm{kg}-{ }^{\circ} \mathrm{C}$
$C_{\text {sb }, \text { flood }}$
flooding factor from Fig. 18-10 (12)
D
distillate rate, $\mathrm{kmol} / \mathrm{h}$
$\mathrm{D}_{\mathrm{T}}$
column diameter, $m$
$\Sigma E$
total amount of water evaporated, $\mathrm{kg} / \mathrm{h}$
$F$
feed flow rate, $\mathrm{kmol} / \mathrm{h}$
$F_{1 v}$
flooding factor used in Fig. 18-10 (12)
$\Delta \mathrm{H}_{\text {vap }}$
heat of vaporization, $\mathrm{kJ} / \mathrm{kg}$
$h_{f}, h_{s}, h_{b}, h_{d}, h_{c}$ enthalpy of feed, steam, bottoms, distillate, and condensate streams, $\mathrm{kJ} / \mathrm{kg}$
L liquid flow rate, $\mathrm{kmol} / \mathrm{h}$
in mass flow rate, $\mathrm{kg} / \mathrm{h}$
$n \quad$ number of effects
$\mathrm{N}_{f}$ feed concentration of salt, wt \%
$\mathrm{N}_{\mathrm{p}} \quad$ product concentration of salt, wt $\%$
$\mathrm{P} \quad$ product stream, $\mathrm{kg} / \mathrm{h}$
$q_{1} \quad$ heat transfer rate, $\mathrm{kJ} / \mathrm{h}$
Q refrigeration duty, ST/D
$Q_{c} \quad$ condenser duty, kJ/h
$Q_{\max } \quad$ volumetric gas flow rate, $1 / \mathrm{s}$
$\mathrm{R} \quad$ reflux ratio, L/V
$R_{\min } \quad$ minimum reflux ratio $\left(R=R_{\min } \times 1.2\right)$ 
$T_{c a}, T_{c b}$ inlet and outlet temperature of cold stream, ${ }^{\circ} \mathrm{C}$

$T_{h a}, T_{h b}$ inlet and outlet temperature of hot stream, ${ }^{\circ} \mathrm{C}$

$\Delta \mathrm{T} \quad$ temperature change, ${ }^{\circ} \mathrm{C}$

$\Delta \mathrm{T}_{1 \mathrm{~m}} \quad$ log mean temperature difference, ${ }^{\circ} \mathrm{C}$

$U_{n f} \quad$ flooding velocity, $\mathrm{ft} / \mathrm{s}$

U vapor velocity, $\mathrm{ft} / \mathrm{s}$

$U_{a v} \quad$ average heat transfer coefficient, $\mathrm{kJ} / \mathrm{h}-\mathrm{m}^{2}-{ }^{\circ} \mathrm{C}$

$\checkmark \quad$ vapor flow rate, $\mathrm{kmol} / \mathrm{h}$

$V_{\text {solids }} \quad$ filter processing volume, $\mathrm{ft}^{3} / \mathrm{h}$

W cooling water flow rate, $\mathrm{kg} / \mathrm{h}$

$X$ mole fraction in the liquid phase

$x_{b}, x_{d}, x_{f}$ bottoms, distillate, and feed mole fraction of butanol

$Y$ mole fraction in the vapor phase

\section{Greek Symbol's}

$\Delta_{1}$

$\Sigma \Delta$

$\Sigma A$

$\lambda$

$\rho_{L}$

$\rho_{v}$

Fsoilids temperature drop in first effect, ${ }^{\circ} \mathrm{C}$ overall temperature drop for all effects, ${ }^{\circ} \mathrm{C}$ total heat transfer àrea

latent heat of vaporization, $\mathrm{kJ} / \mathrm{kg}$

1 iquid density, $\mathrm{kg} / 1$

vapor density, $\mathrm{kg} / \mathrm{l}$

solids density, $1 b / f t^{3}$ 


\subsection{Literature References}

1. Bauman, H.C., Fundamentals of Cost Engineering in the Chemical Industry, p. 2, Reinhold, New York, 1964.

2. McCabe, W.L., and J.C. Smith, Unit Operations of Chemical Engineering, 3rd ed., McGraw-Hill, New York, 1976.

3. Treybal, R.E., Mass-Transfer Operations, 3rd ed., McGraw-Hill, New York, 1980.

4. Benedict, M., and Rubin, L.C., "Extractive and Azeotropic Distillation," Nat. Petrol. News, $37(36)$ (Sept. 5, 1945)

5. Smith, B.D., Design of Equilibrium Stage Processes, McGraw-Hi11, New York, 1963. 1981.

6. Donaldson, T.L., personal communication (7etter), June 5,

7. Prescott, S.C., and C.G. Dunn. Industrial Microbiology, 3rd ed., pp. 250-293, McGraw-Hi11, New York, 1959.

8. Shreve, R.N., and J.A. Brink, Chemical Process Industries, 4th ed., p. 531, McGraw-Hi11, New York, 1977.

9. Strobel, M.K., and J.B. Bader,. "Economic Evaluation of NeutralSolvents Fermentation Product Separation," ORNL/MIT-330, July 1981.

10. Stcphen, $H_{.}$, and $T$. Stcphen, eds., Solubilities of Inorganir and Organic Compounds, Vol. 2, Ternary Systems-Part 1, MacMillan Company, New York, 1964.

11. "Biotechnology for Producing Fuels and Chemicals from BiomassVolume II - Fermentation Chemicals From Biomass," Ruxton Villet, ed., SERI/TR-621-754, pp. 1-45, February 1981.

12. Perry, R.H., and C.H. Chilton, eds., Chemical Engineers' Handbook, 5th ed., McGraw-Hi11, New York, 1973.

13. Schweitzer, P.A., ed., Handbook of Separation Techniques for Chemical Engineers, McGraw-Hil1, New York, 1979.

14. Coates, J., "Simplified Method for Estimating Evaporator Capacity and Steam Consumption," Chem. Eng. Prog., 45(1), 25 (January 1949).

15. Peters, M.S., and K.D. Timmcrhaus, Plant Design and Economics for Chemical Engineers, 3rd ed., McGraw-Hill, New York, 1980.

16. Chemical Engineering, $88(20), 9$ (0ctober 5, 1981). 
17. Beesch, S.C., Appl. Microbiol., I, 85 (1953).

18. Chemical Marketing Reporter, Schnell Publishing Co., Oct. 5, 1981.

19. Azeotropic Data, compiled by L.H. Horsley, published June 1952 by the American Chemical Society.

20. Lange's Handbook of Chemistry, 11 th ed., J.A. Dean, ed., McGrawHill, New York, 1973. 


\section{THIS PAGE \\ WAS INTENTIONALLY \\ LEFT BLANK}


ORNL/MIT-338

INTERNAL DISTRIBUTION

1. C.H. Brown

2. A.L. Compere

3-7. T.L. Donaldson

8. D.E. Ferguson

9. W.L. Griffith

10. J.R. Hightower

11. G.E. Moore

12. C.D. Scott

13. S.E. Shumate II

14. G.W. Strandberg

15. J.S. Watson

16. R.G. Wymer

17-18. Centra7 Research Library

19. Document Reference Section

20-22. Laboratory Records

23. Laboratory Records, ORNL R.C.

24. ORNL Patent Office

25-39. MIT Practice School

\section{EXTERNAL DISTRIBUTION.}

40. M.M. Alger, MIT, GE, Selkirk, NY 12158

41. W.C. Rousseau, MIT, Cambridge, MA 02139

42. J.W. Tester, MIT, Cambridge, MA 02139

43. J.E. Vivian, MIT, Cambridge, MA 02139

44. Morgantown Energy Technology Center P.0. Box 880, Morgantown, WV 26505

45. Office Assl. Myr., Erleryy R\&D, DOE, Oak Ridye 46-72. Technical Information Center 
Do Nor

MiCROFICM 